\title{
Retinal Afferent Ingrowth to Neocortical Transplants in the Adult Rat Superior Colliculus is due to the Regeneration of Damaged
}

\author{
Axons \\ D.T. Ross ${ }^{1}$ and G.D. Das ${ }^{2}$ \\ ${ }^{1}$ Head Injury Center, Division of Neurosurgery, University of Pennsylvania, Philadelphia, PA \\ and ${ }^{2}$ Department of Biological Sciences, Purdue University, West Lafayette, IN, USA
}

\begin{abstract}
SUMMARY
Retinal afferent ingrowth to embryonic neural transplants in the adult rat superior colliculus may represent either sprouting of intact axons or the regeneration of transected axons. If ingrowth represents regeneration of damaged retinofugal axons, then lesions that axotomize more retinofugal axons at the transplantation site should induce greater retinal afferent ingrowth. Alternately, if ingrowth represents terminal or collateral sprouting of intact retinofugal axons at or near the transplant/host optic layer interface, then the magnitude of retinal afferent ingrowth should be directly related to the total area of this interface. To test between these two hypotheses surgical knife wounds were made either parallel (in the sagittal plane) or perpendicular (in the transverse plane) to the course of axons in the stratum opticum, embryonic neocortical tissue was transplanted at the coordinates of these tectal slits, and retinal afferent ingrowth visualized 1-90 days after surgery using anterogradely transported HRP.
\end{abstract}

A zone of traumatic reaction (ztr) in the optic layers was seen in every case, characterized by hypertrophied axons and swollen terminal clubs at 1 day. Between 30 and 90 days the damaged retinofugal axons in the zone formed dense fascicles and neuroma-like tangles. Retinal afferent ingrowth occurred only across

Reprint address:

Douglas T. Ross, Ph.D.

Division of Neurosurgery

University of Pennsylvania

3400 Spruce Street

Philadelphia, PA 19104-4283, USA transplant interface regions with the $z$ tr. The magnitude of ingrowth was directly related to the area of the $z$ tr interface and not the total optic layer interface area. Retinal afferent ingrowth appears to reflect the intrinsic regenerative capacity of adult mammalian retinal ganglion cells and not sprouting of undamaged axons.

\section{KEY WORDS}

axonal regeneration, retinal ganglion cells, neural transplantation, retinofugal projection

\section{INTRODUCTION}

Modern neural transplantation research began with the studies of Das and Altman /18,19/ and Das $/ 20,22 /$ which established that tissues from numerous regions of the embryonic neuraxis survived and grew following transplantation into the brains of neonatal or adult rat hosts. This early work excited an intense interest in transplantation, Dr. Das's enduring legacy, built largely on the promise that transplantation may permit functional recovery through re-establishment of damaged circuitries. Despite two decades of research, this potential still remains to be fully realized. Limitations posed by the nature of the adult brain itself, i.e. the complex environment it provides to axons growing out of transplants and its very limited capacity for axonal regeneration, severely restrict the extent of transplant integration with the host brain.

The primary focus of research in the Das laboratory was always upon the study of properties of neural transplantation per se, and was not closely 
associated with reconstruction of any particular brain system. The present study grew out of other work performed in his laboratory and reflects emerging ideas of what controls the ingrowth of axons into transplants. Das's early work had verified that the phenotype of transplant neurons was clearly dictated by the region of the embryonic neuraxis from which the transplant was obtained $/ 18,19,20,22 /$, but Das (personal communication) hypothesized that connections formed between transplant and host brain were determined by the site into which the tissue was transplanted. The results of Oblinger and Das $/ 82,83 /$ confirmed that afferents to neocortical transplants in the cerebellar hemisphere arose from host precerebellar fiber systems in the proximity of the interface and were, therefore, "non-specific" for the type of tissue transplanted. These studies also established that the magnitude of afferent ingrowth was a function of the developmental stage of the host at the time of transplantation. The relatively exuberant ingrowth of precerebellar afferents to neocortical transplants placed in the cerebellum of young neonatal hosts reflected the greater "neuroplasticity" of developing axons, manifest as either redirected normal growth or a compensatory collateral hypertrophy following injury $/ 83 /$. These mechanisms appear to account for most afferent innervation of embryonic neural tissues transplanted into a variety of regions within the CNS of neonatal animals $/ 8,9,10,15,42,43,52$, $59,67,68,72,78,97 /$.

The relatively meager amount of afferent ingrowth into neocortical transplants in the cerebellum of adult hosts was thought to reflect either a limited capacity for sprouting of undamaged precerebellar fibers or feeble efforts at regenerative growth by damaged axons /82/. Intact axons of some adult mammalian CNS fiber systems exhibit a very marked capacity for sprouting in response to the presence of adjacent deafferented post synaptic sites $/ 17,70,74,80,81,92,93,119,125 /$. Alternately, it is now well established that damaged axons from adult neuromodulatory cholinergic, serotonergic, dopaminergic, noradrenergic, and neuropeptide systems may regenerate /98/ and exuberantly innervate transplants of embryonic neural tissues $/ 13,23$, $24,25,49,51,57,58,64,65,87,137 /$. In contrast, the ingrowth of axons from putatively glutamatergic specific projection systems into solid transplants is meager at best $/ 28,29,48,53,87,91,106,136,137 /$ or even non-existent $/ 131 /$. Intact axons from many of these specific projection systems, however, are capable of innervating neurons in cell suspension grafts embedded within the host neuropil through the reactive synaptogenesis from terminals on nearby host neurons $/ 24,60 /$. Most neuronal populations that give rise to specific projection systems, such as the pontocerebellar and olivocerebellar projections, use excitatory amino acids as their transmitters $/ 76 /$. In general neurons in these systems do not exhibit a sustained regenerative response to axonal injury $/ 11,96 /$, but instead may undergo either neuronal death following rapid retrograde degeneration $/ 6,105 /$, or may persist but exhibit gradual perikaryal atrophy and a slow dying back of damaged axons $156,89,96 /$. The response of the putatively glutamatergic retinal ganglion cells to axonal injury appears to be, under some circumstances, an exception to Ramon y Cajal's /96/ dire pronouncement that in these systems "... everything must die, nothing may regenerate".

Our early studies $/ 100,104,108$ / established that transplants of embryonic neocortical tissue in the caudal diencephalon or superior colliculus of adult rats received a retinal afferent projection. Retinal afferent ingrowth occurred only across those interface regions where damaged host retinofugal axons were present and entered the transplants with their normal trajectories. These observations suggested, but did not causally require, that damaged axons gave rise to the retinal afferent projection. The sprouting of undamaged retinofugal axons across optic layer interface regions into the transplants could not be ruled out. In subsequent studies we established that damage to retinal ganglion cell axons at the level of the optic tract or brachium of the superior colliculus, main trunk regions of the central retinofugal projection, resulted in sustained regenerative growth $/ 101,102$, $103,108 /$. Axonal regeneration was manifest as the formation of neuroma-like tangled masses of retinofugal axons within the zone of traumatic reaction $/ 103,108 /$, the exuberant growth of fascicles of regenerated retinofugal axons upon connective tissue elements in optic tract or 
brachium transection cavities $/ 103,108 /$, or the growth of these axons into or through transplants of embryonic neural tissue with apparent reinnervation of deafferented regions of the optic layers of the superior colliculus $/ 101,102,103,108 /$. Subsequent studies have demonstrated that, following transection of the main trunk of the retinofugal projection at the level of the optic nerve, the small population of surviving retinal ganglion cells may also express a capacity for axonal regeneration in the form of growth into or through peripheral nerve grafts $/ 3,14,31,35,109,116,122,123,126,127,129$, $130,133,134,138 /$.

The present study examined whether ingrowth of retinal afferents to embryonic neural tissue transplanted into the optic layers of the superior colliculus was due to regeneration of damaged axons or sprouting of intact axons. We reasoned that if retinal afferent ingrowth to transplants in the adult superior colliculus was due to the terminal or collateral sprouting of intact axons at or near the transplant/host optic layer interface, then the magnitude of ingrowth should be directly related to the total area of this interface. Alternately, if it was necessary to damage retinofugal axons at the transplantation site in order to elicit retinal afferent ingrowth to the transplants, and if ingrowing fibers are actually damaged axons that regenerate, then pre-transplantation surgical lesions that axotomize larger populations of retinofugal axons at the transplantation site should result in greater amounts of retinal afferent ingrowth to the transplants. To test between the sprouting and regeneration hypotheses of retinal afferent ingrowth to transplants, $2 \mathrm{~mm}$ long surgical knife wounds were made either parallel (in the sagittal plane) or perpendicular (in the transverse plane) to the course of axons in the stratum opticum and embryonic neocortical tissue was transplanted at the coordinates of these tectal slits. Retinal afferent ingrowth was visualized 90 days after lesion/ transplantation surgery using anterogradely transported HRP.

\section{MATERIALS AND METHODS}

Adult female Long-Evans rats (4 months old, 280-320 g) were anesthetized with ketamine (87 $\mathrm{mg} / \mathrm{kg}$, i.m.), supplemented with the analgesic xylazine (13 mg/kg, i.m.), mounted in a headholder, and prepared for stereotaxic surgery. This study employed a modification of the stereotaxic technique of Das and Ross /21/ in which surgical knife wounds were made in the superior colliculus immediately prior to transplantation of embryonic neural tissue. A \#11 scalpel blade (Bard-Parker), ground down behind the cutting edge to produce a long thin blade, was affixed to an electrode holder and secured to one electrode carrier on a twoarmed stereotaxic instrument (David Kopf, Tujunga CA). Three groups of animals received bilateral lesions only. Sagittal wounds (SAG-X, $n=8$ ) were made by lowering the knife vertically into the parenchyma of the superior colliculus at coordinates $4.0 \mathrm{~mm}$ posterior to the bregma, $2.0 \mathrm{~mm}$ lateral to midline, $5.5 \mathrm{~mm}$ below the dural surface, and moving the blade antero-posteriorly $2.2 \mathrm{~mm}$ in the sagittal plane. Transverse wounds (TRANS-X, $n=6$ ) were made by lowering the knife to coordinates 5.0 $\mathrm{mm}$ posterior to the bregma, $2.0 \mathrm{~mm}$ lateral to midline, $5.5 \mathrm{~mm}$ below the dural surface, and moving the blade medio-laterally $2.0 \mathrm{~mm}$ in the transverse plane. A third type of stab wound (TN$\mathrm{X}, \mathrm{n}=6$ ) was made by vertically lowering and removing the beveled glass transplantation needle $(0.8 \mathrm{~mm} \mathrm{O.D.)}$ to coordinates $5.0 \mathrm{~mm}$ posterior to the bregma, $2.0 \mathrm{~mm}$ lateral to midline, and $5.5 \mathrm{~mm}$ below the dural surface. In three other groups surgical stab wounds were followed immediately by stereotaxic transplantation of 17 day embryonic neocortical tissue $\left(2.5-3.5 \mathrm{~mm}^{3}\right)$ at the midpoint of the lesion cavity via the carrier syringe affixed to the second electrode carrier. One group received sagittal lesions followed by transplants (SXTRT, $\mathrm{n}=10$ ), another group received transverse lesions followed by transplants (TXTRT, $n=7$ ), and a third group of animals (TRT, $\mathrm{n}=6$ ) received focal lesions in their superior colliculus by the beveled glass capillary needle during the process of transplantation.

All animals received single intravitreal injections of HRP (4 $\mu 125 \%$ Sigma Type VI in lactated 
Ringer's solution) in the eye contralateral to the lesion or transplant 24 hours prior to sacrifice. All animals in the lesion/transplant groups were sacrificed after 90 days survival. For each lesion group four animals were sacrificed 1 day after injury and two animals per group were sacrificed at either 30 days (SAG-X group) or 90 days (TN-X and TRANS-X groups). Adult female Long-Evans rats (4 months old, $n=4$ ) that received intravitreal HRP injections served as normal (non-lesion) controls. All animals were perfused with $2.0 \%$ glutaraldehyde, $0.5 \%$ paraformaldehyde in $0.1 \mathrm{M}$ phosphate buffered saline, and frozen coronal $40 \mu \mathrm{m}$ sections were cut and processed for HRP histochemistry using Adams's /1/ modification of Mesulam's /77/ tetramethyl-benzadine chromagen technique. Due to the orientation of the transverse tectal slits, and the fact that transplants placed in transverse slits developed extensive rostral interface regions with the optic layers, several brains in the TRANS-X and TXTRT groups were cut at $40 \mu \mathrm{m}$ in the sagittal plane and processed as previously described.

Neocortical transplants and their interface regions with the host optic layers were easily distinguishable, due to characteristic differences in cytology and cytoarchitecture. In all cases the optic layers of the superior colliculus, stratum opticum (so) and stratum griseum superficiale (sgs), rostral to lesions or transplant interfaces were examined for the presence of swollen axonal segments and greatly enlarged terminal clubs on the proximal stumps of the damaged retinofugal axons, defining the extent of the zone of traumatic reaction (ztr). Optic layer regions medial and caudal to lesions were examined for the presence of zones of complete or partial retinal deafferentation in all cases. Both transplant interface and parenchymal regions were examined for the presence of HRP labeled fibers or terminals in all lesion/transplantation animals. Polarized light optics $/ 46,50$ / were used to reliably detect the HRPTMB reaction product at low power. Lesion/ transplant brains were selected for quantitative analysis based upon the following criteria: 1) successful HRP injections which intensely labeled the entire retinofugal projection; 2) verification of the lesion orientation, and 3 ) the presence of a well integrated transplant interface with the optic layers. The following criteria were used for identifying
HRP labeled axons as retinal afferents to neocortical transplants: 1) penetration at least $50 \mu \mathrm{m}$ across clearly defined interface positions in at least two consecutive sections; 2 ) the presence of positively identified neocortical neurons at both the position of suspected ingrowth and at corresponding positions in adjacent sections, and 3) the absence of spared fascicles of intact host retinofugal axons at these positions in adjacent sections. Using these criteria it was possible to overcome any uncertainty about the exact position of the interface and to insure that labeled fibers identified as retinal afferents were not part of the spared host retinofugal projection that only appeared to enter the transplant due to the plane of sectioning. Low power (83x) drawings were made of alternate $40 \mu \mathrm{m}$ sections throughout the superior colliculus of all normal control cases and cases which had received stab wounds using a Wild M-20 microscope with a drawing tube attachment. For each animal in the three lesion groups 280x drawings of the retinofugal zone of traumatic reaction were made. For each lesion/ transplant case selected for quantitative analysis of retinal afferent ingrowth, high power (280x) drawings were made of all transplant-optic layer interface regions and adjacent regions of the transplant parenchyma which contained HRPlabeled retinofugal axons and terminals, and low power (83x) drawings of all alternate $40 \mu \mathrm{m}$ sections containing either transplant or the optic layers of the superior colliculus were also made. Using a Hewlett-Packard Model $10 \mathrm{X}-\mathrm{Y}$ digitizer panel linked to a Hewlett-Packard Model 9830A computer, scaled to compensate for areal and linear magnification and convert units to $\mathrm{mm}^{3}$ and $\mathrm{mm}^{2}$, respectively, the cross sectional area of the zone of traumatic reaction, volume of the optic layers, and volume of retinal deafferentation were determined from drawings for each lesion case. The transplant volume, volume of transplant innervated by the retinofugal projection, host optic layer volume, transplant-optic layer interface surface area, and the optic layer/transplant interface area across which retinal afferents penetrated, were determined for each lesion-transplantation case. For all parameters measured in the lesion, lesion/transplantation, and normal control groups, means and standard deviations were determined and compared across 
groups using Student's t-test. Correlations between the parameters were determined from linear regression analysis by determining Pearson's correlation coefficient ( $r$ ), and the strength of these correlations was verified using a one way analysis of variance (F-test).

\section{RESULTS}

\section{Lesions in the superior colliculus}

Four regions were identified in the superior colliculus of all experimental cases (Figure 1). The first region, the zone of normal axonal segments, was characterized by fibers in the stratum opticum indistinguishable from normal undamaged axons. Distal to the zone of normal segments a zone of traumatic reaction (ztr) was evident. Caudal to the ztr a blood filled lesion cavity extended from the overlying occipital cortex, through the optic layers, and into the underlying deeper layers of the superior colliculus. In the optic layers caudal and sometimes medial to the lesion cavity, zones of retinal deafferentation were seen. The appearance of representative regions from $\mathrm{TN}-\mathrm{X}, \mathrm{SAG}-\mathrm{X}$ and TRANS- $X$ cases can be seen in Figures 2, 3 and 4 respectively.

Regions in the optic lavers of the traumatized superior colliculus

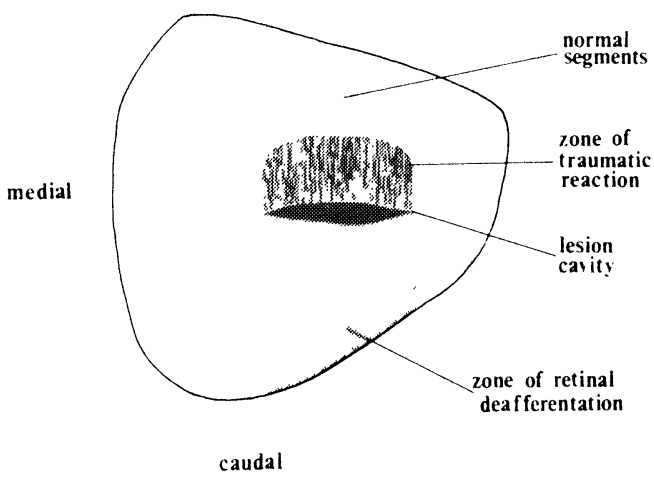

Fig. 1: Schematic representation of regions in the optic layers of the traumatized superior colliculus.

\section{Zone of traumatic reaction}

A zone of traumatic reaction in the stratum opticum extended $400-600 \mu \mathrm{m}$ retinopetally from the rostral margin of the lesion cavity in all cases (Figure 2B, 3A, 4A). One day following injury hypertrophied segments of damaged axons, intensely labeled with HRP, were present throughout the entire length of the zone in all three lesion groups. Proximal to the lesion cavity these hypertrophied axonal segments were either capped with swollen terminal clubs or varicose segments, some of which extended to the wound margin (Figure 5). The cross sectional area of the zone of traumatic reaction proximal to the lesion cavity for each lesion group 1 day after injury is given in Figure 6A. By 30 days after injury varicose axons, some of which had clearly aberrant trajectories, were evident at the scar and throughout the length of the zone of traumatic reaction in the optic layers. In SAG-X cases examined 30 days after injury the ztr was characterized by small fascicles of darkly labeled axons present throughout its anteroposterior extent, and a few HRP labeled retinofugal axons capped by swollen terminal clubs lateral to the lesion cavity or scar. These damaged axons were found mainly in the stratum griseum superficiale and were occasionally seen in the stratum opticum in the caudal part of the zone of traumatic reaction. Ninety days after TRANS-X injury thick, dense fascicles of darkly labeled axons and neuroma-like tangled masses of HRP labeled axons were present within the zone of traumatic reaction in TRANS-X cases proximal to the scar (Figure 7).

\section{Zone of retinal deafferentation}

Immediately caudal to the lesion cavity a small zone of partial retinal deafferentation was evident in $\mathrm{TN}-\mathrm{X}$ cases, representing about $2 \%$ of the total volume of the optic layers (Figure 2D, Figure 8A). Similar zones of partial retinal deafferentation, representing only $1.5 \%$ of the total volume of the optic layers, were evident medial and caudal to SAG-X lesion cavities (Figure 8B). In the optic 


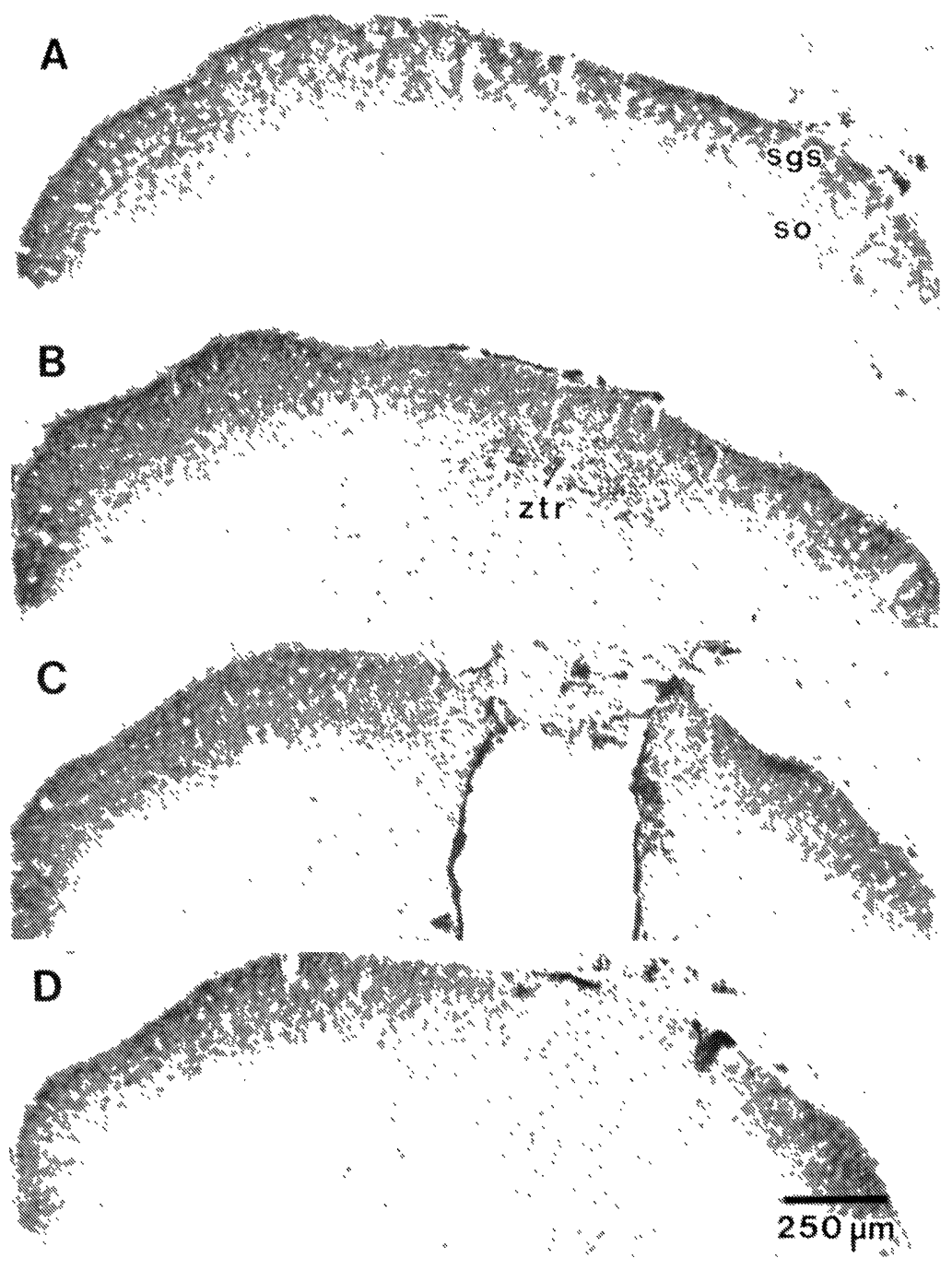

Fig. 2: Regions of the optic layers, stratum opticum (so) and stratum griseum superficiale (sgs), associated with transplantation needle lesions, 1 day after injury, retinofugal fibers labeled by HRP injection in the contralateral eye, TMB histochemistry, thionin counterstain. A. Zone of normal segments. B. Zone of traumatic reaction (ztr). C. Transplantation needle lesion site. D. Zone of partial retinal deafferentation.

layers immediately caudal to TRANS-X lesion sites, a zone of complete retinal deafferentation, representing about $14 \%$ of the total volume of the optic layers, was present (Figures 4B, 7A). The mean volume of the optic layers deafferented by each type of lesion is given in Figure 6B.

\section{Neocortical transplants in the superior colliculus}

All TRT and TXTRT cases developed large, well-differentiated and well-integrated transplants which were easily distinguishable from the host brain by their cytology and cytoarchitecture. Cytologically, these transplants contained normal compliments of healthy neocortical pyramidal and non-pyramidal neurons, a normal compliment of glia, and a healthy appearing neuropil. All transplants in these two groups were well integrated with the host tectal parenchyma and had extensive interface regions with the host optic layers along their medial and lateral (TRT) or rostral and medial 


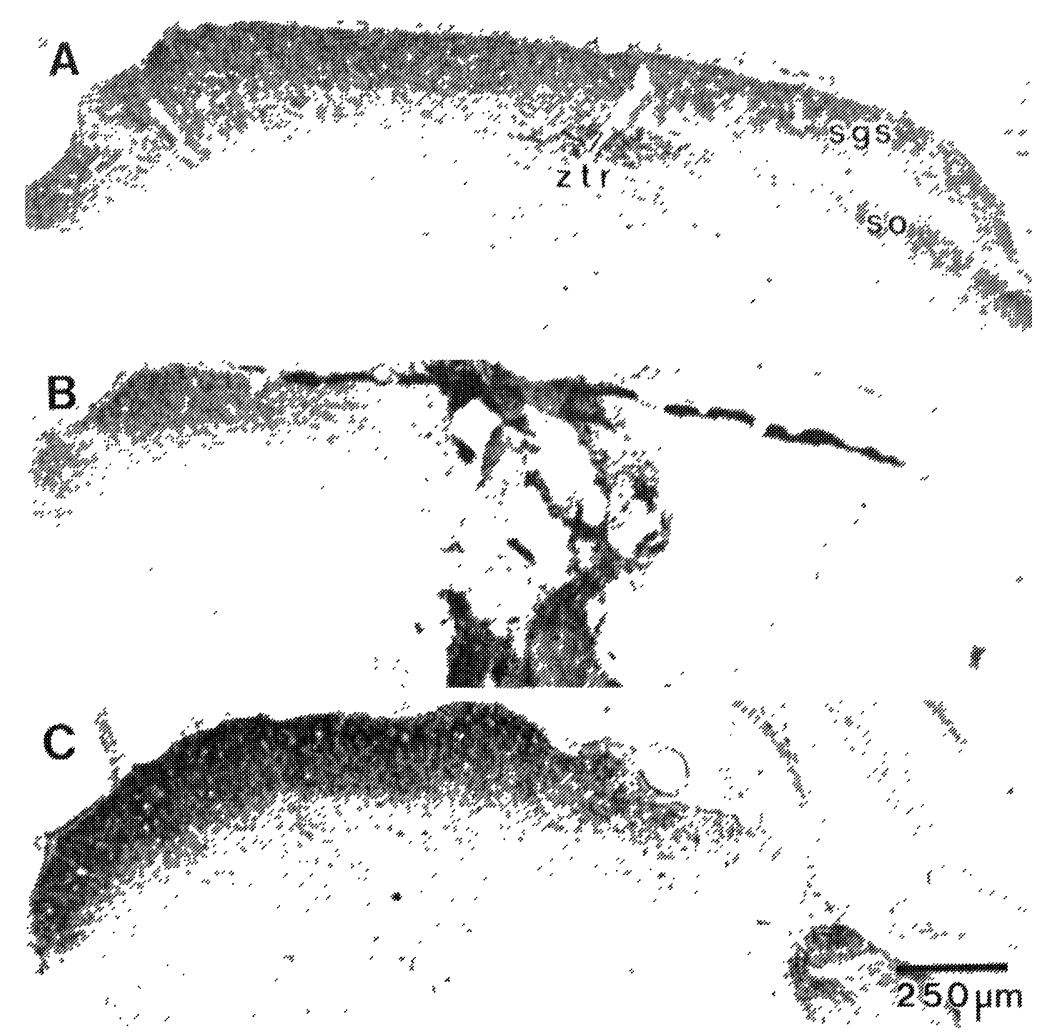

Fig. 3: Regions of the optic layers associated with sagittal surgical knife lesions. A. Zone of traumatic reaction (ztr), 1 day after injury. B. Sagittal knife lesion site, 1 day after injury. C. Sagittal knife lesion site, 30 days after injury. Retinofugal fibers labeled by HRP injection in the contralateral eye, TMB histochemistry, thionin counterstain.

(TXTRT) borders. Well-differentiated, wellintegrated neocortical transplants were found in the superior colliculi in eight of 11 SXTRT cases. In the other three cases extensive intraparenchymal bleeding had been noted at the time of surgery, and there was clear evidence of pathological reaction in both transplant and host brain three months after transplantation. In three of the eight cases with well integrated transplants the sagittal tectal slits extended rostrally into the brachium, retinal afferents penetrated across interfaces at these positions, and substantial zones of complete retinal deafferentation were present in the optic layers along the medial transplant interface. Only the four SXTRT cases with healthy, well integrated transplants, host retinofugal projection interfaces limited to the optic layers, and HRP injections that labeled the entire retinofugal projection were used for quantitative analysis.

Volume of the spared optic layers and optic layer interface area

The mean area of optic layer interface for the transplants in the three groups is given in Figure 9. The mean volume of the host optic layers medial and lateral to transplants in the TRT group was $1.83 \mathrm{~mm}^{3} \pm 0.10 \mathrm{~mm}^{3}$ S.D., significantly less than the volume of the optic layers in normal control animals $(82 \%, \mathrm{p}<0.01)$. The mean volume of the spared optic layers medial and lateral to SXTRT transplants was $1.90 \mathrm{~mm}^{3} \pm 0.34 \mathrm{~mm}^{3}$ S.D. This represented $85 \%$ of the volume of the optic layers in age matched controls, and was not significantly 


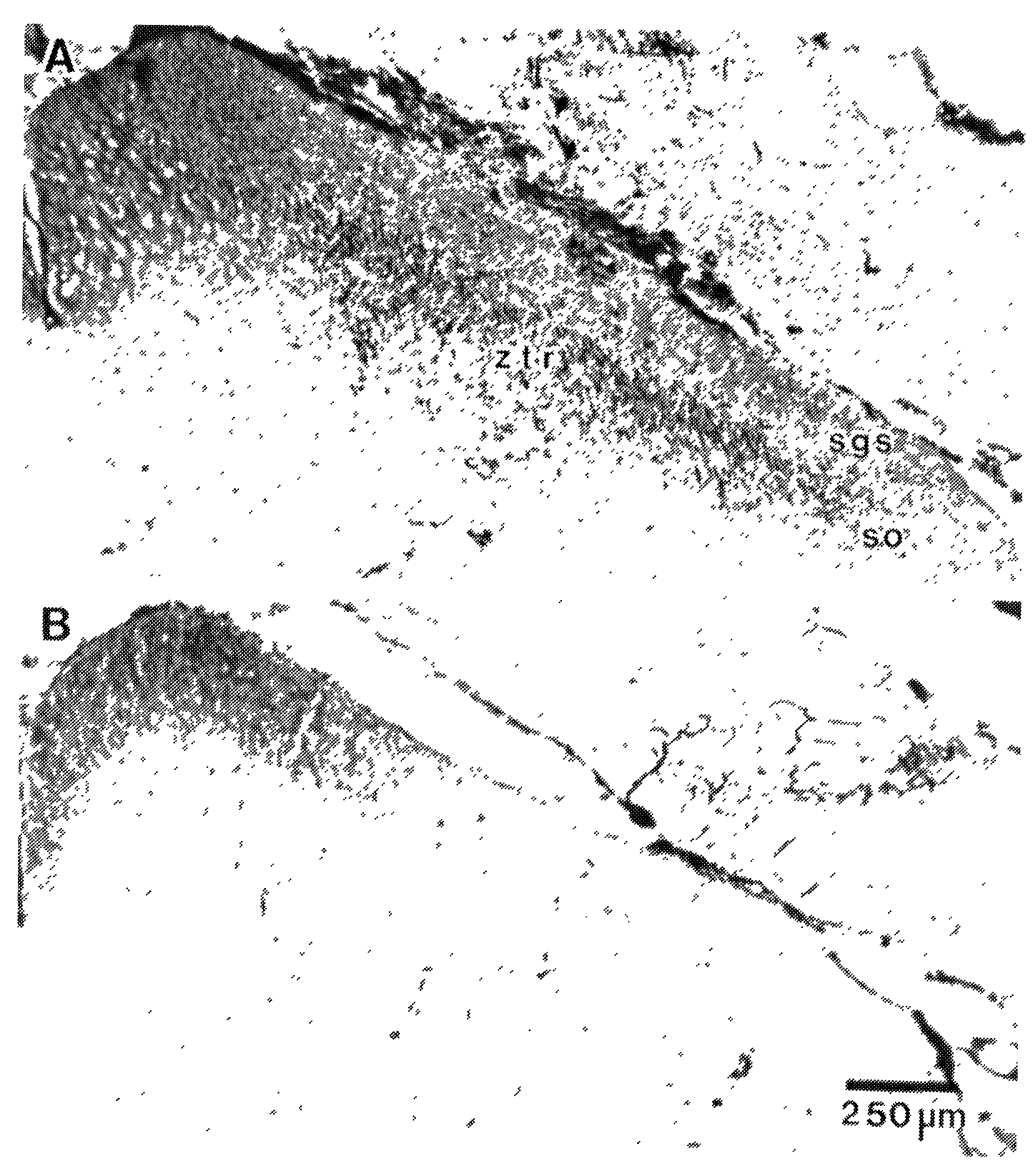

Fig. 4: Regions of the optic layers associated with transverse surgical knife lesions, 1 day after injury. A. Zone of traumatic reaction (ztr). B. Zone of complete retinal deafferentation. Retinofugal fibers labeled by HRP injection in the contralateral eye, TMB histochemistry, thionin counterstain.

different from the volume of the spared optic layers in the TRT group $(p<0.50)$. The mean volume of the host optic layers medial and rostral to the transplants in the TXTRT group was $1.71 \mathrm{~mm}^{3} \pm$ $0.22 \mathrm{~mm}^{3}$ S.D. This was significantly less than the volume of the optic layers in normal control animals $(p<0.01)$, representing only $76 \%$ of the control volume. This volume was, however, not significantly less than the volume of spared optic layers in either the TRT or SXTRT groups $(\mathrm{p}<0.50)$.

\section{Zone of traumatic reaction}

In every case from all three groups a zone of traumatic reaction was present in the optic layers extending retinopetally $400-600 \mu \mathrm{m}$ from the rostro-lateral optic layer interface. The appearance of the zone was similar, but not identical, to that seen at equivalent times after injury in cases receiving lesions without transplants (Figure 10). The optic layers lateral to transplants in the SXTRT group appeared physically distorted, greatly compressed, and distended dorso-laterally and were characterized by numerous varicose axons and axons capped by terminal clubs (Figure 13B). In the TXTRT group a very pronounced zone of traumatic reaction was evident, characterized by occasional dense fascicles of HRP labeled axons and a few neuroma-like tangled masses of HRP labeled axons 


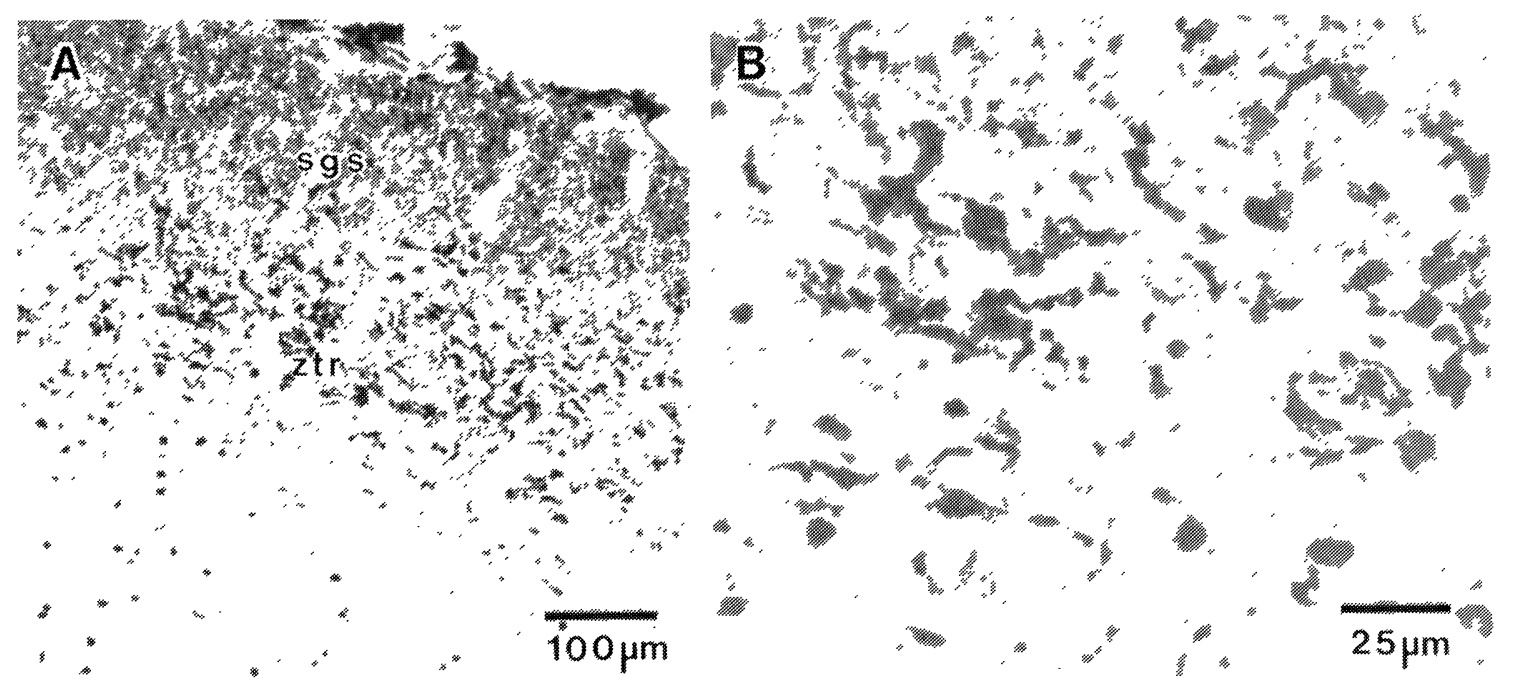

Fig. 5: Detail of the zone of traumatic reaction rostral to a transplantation needle lesion, 1 day after injury. A. A distinctive zone of traumatic reaction characterized by intensely HRP labeled fibers in the stratum opticum. B. At higher power the intensely HRP labeled elements in the ztr appear as hypertrophied proximal axonal segments and terminal clubs. Retinofugal fibers labeled by HRP injection in the contralateral cyc, TMB histochemistry, thionin counterstain.

proximal to some interface regions. These neoformations were much less pronounced than those present in cases that received similar lesions without transplants, the TRANS-X group. HRP labeled retinofugal axons crossed optic layer interface regions into transplants in all three groups from positions which corresponded, in every case, to the zone of traumatic reaction. The mean area of the transplant/ztr interface in the SXTRT, TRT and TXTRT groups represented $2.65 \%, 5.96 \%$, and $36.28 \%$ of the total transplant optic layer interface, respectively. Whereas in the TRT and SXTRT groups HRP labeled retinal axons penetrated across very restricted lateral interface regions with the ztr, in TXTRT cases HRP labeled axons penetrated across their relatively extensive rostral interface with the ztr in the optic layers. The mean area of transplant interface regions across which retinal afferents penetrated, the interface with the zone of traumatic reaction (ztr), for each group is given in Figure 11A.

\section{Retinal afferent projection}

In the TRT and SXTRT groups HRP labeled retinal afferents penetrated up to $150 \mu \mathrm{m}$ into the transplant parenchyma and appeared to terminate in close proximity to neocortical pyramidal and nonpyramidal neurons in the transplant neuropil where they occupied a very small volume of the transplant (Figures 12 and 13A). A relatively profuse retinal afferent projection penetrated across interface positions with the zone of traumatic reaction in TXTRT cases, extending up to $800 \mu \mathrm{m}$ into the transplant parenchyma, and terminated in many patches of varying'density in and around neocortical neuron dense regions (Figure 14). The volume of host retinofugal innervation of transplants in each lesion/transplantation group is shown in Figure 11B. The volume of TRT transplants innervated by the host retinofugal projection averaged $0.09 \%$ of the total transplant volume, represented only $2 \%$ of the volume of the optic layers replaced by the transplant, but was equal to $16.8 \%$ of the volume of the optic layers partially deafferented by similar lesions in the TN-X lesion control animals. In the SXTRT group the volume of transplant innervated by the host retinofugal projection averaged $0.02 \%$ of the total transplant volume, $0.4 \%$ of the volume of the optic layers replaced by the transplant, and 

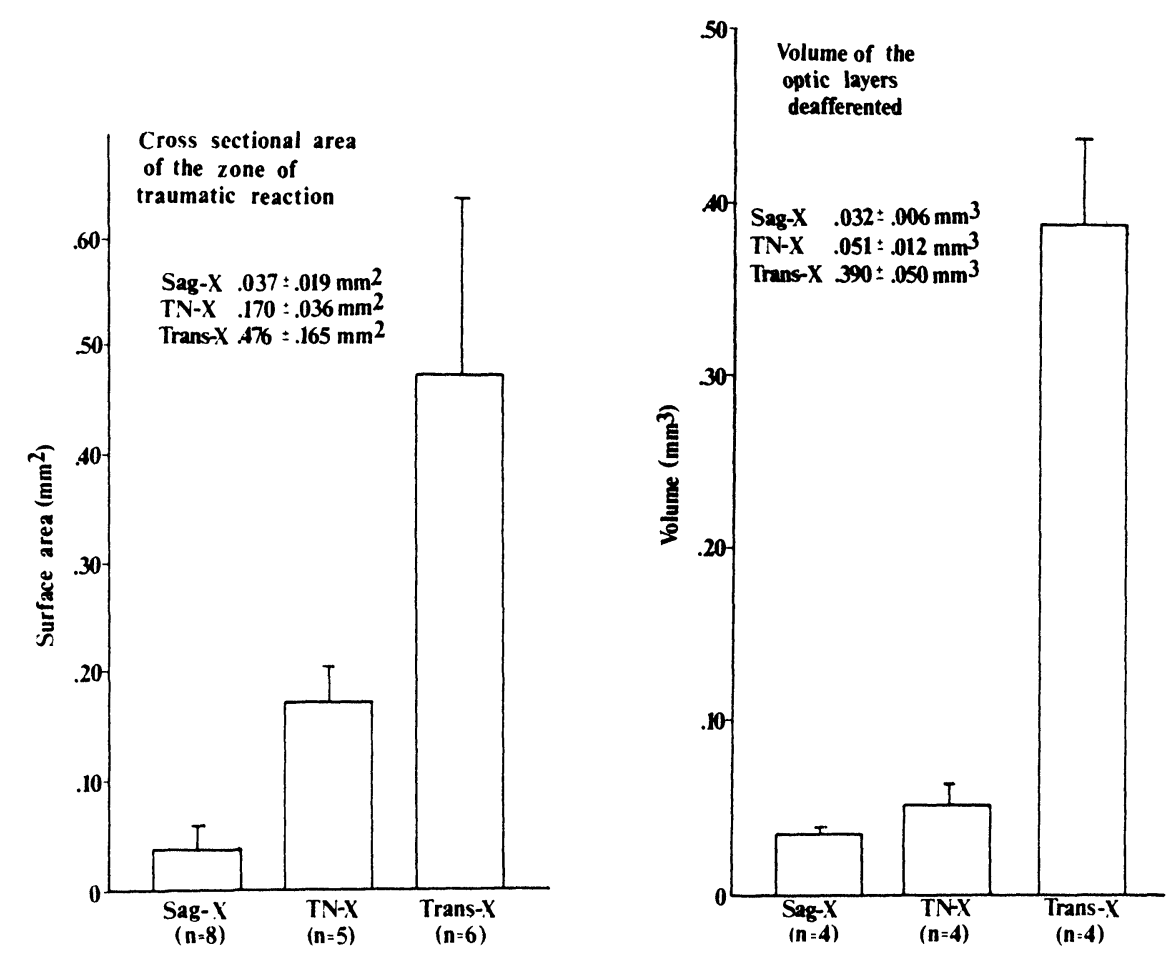

Fig. 6: Quantitative analysis of regions associated with different types of lesions. A. Comparison of the cross sectional area of the zone of traumatic reaction (ztr) for three lesion groups, mean and standard deviation (S.D.) given. The ztr in the SAG-X group was significantly smaller than that seen in the TRT group $(p<0.001)$ and the ztr rostral to transverse lesions was significantly wider than those seen in $T N-X$ and SAG-X cases $(p<0.01$ and $p<0.001$, respectively). B. Comparison of the volume of the optic layers deafferented in the three lesion conditions, mean and standard deviation (S.D.) given. The mean volume of partial retinal deafferentation in the SAG-X group was slightly less than the volume of partial retinal deafferentation seen in the TN-X group, $\mathrm{p}<0.05$. The mean volume of complete retinal deafferentation in the TXTRT group was significantly larger than the volumes of partial deafferentation seen following either focal or sagittal stab wounds, $\mathrm{p}<0.001$.

$5.1 \%$ of the volume of the optic layers partially deafferented by similar sagittal knife lesions in SAG-X animals. The volume of the retinal afferent projection to TXTRT transplants represented only $0.037 \%$ of the total transplant volume, $9.0 \%$ of the volume of the optic layers replaced by the transplants, and $12.8 \%$ of the volume of the optic layers completely deafferented in transverse lesion control animals.

\section{Correlation of surface and volume components}

The volume of retinal deafferentation in the optic layers was highly dependent upon the cross sectional area of the zone of traumatic reaction in the optic layers $(r=0.85, p<0.001 ; F=181, p<0.001)$.
Across all lesion conditions, the area of optic layer interface through which retinal afferents penetrated into transplants was highly correlated with the cross sectional area of the zone of traumatic reaction in the optic layers at the wound margin $(r=0.98$, $p<0.001 ; F=6.95, p<0.005$ ). For all transplants that received retinal afferents, the volume of retinal afferent ingrowth was highly dependent upon the area of the transplant interface across which retinal afferents entered the transplants $(r=0.93, p<0.01$, $F=5.93, p<0.01$, Figure 15). Across all lesion conditions, the volume of retinal afferent ingrowth to transplants was highly correlated with the volume of optic layers deafferented in similar lesion control animals $(r=0.92, \quad p<0.001 ; \quad F=5.93, \quad p<0.01) . \quad A$ slightly negative correlation was found between the 


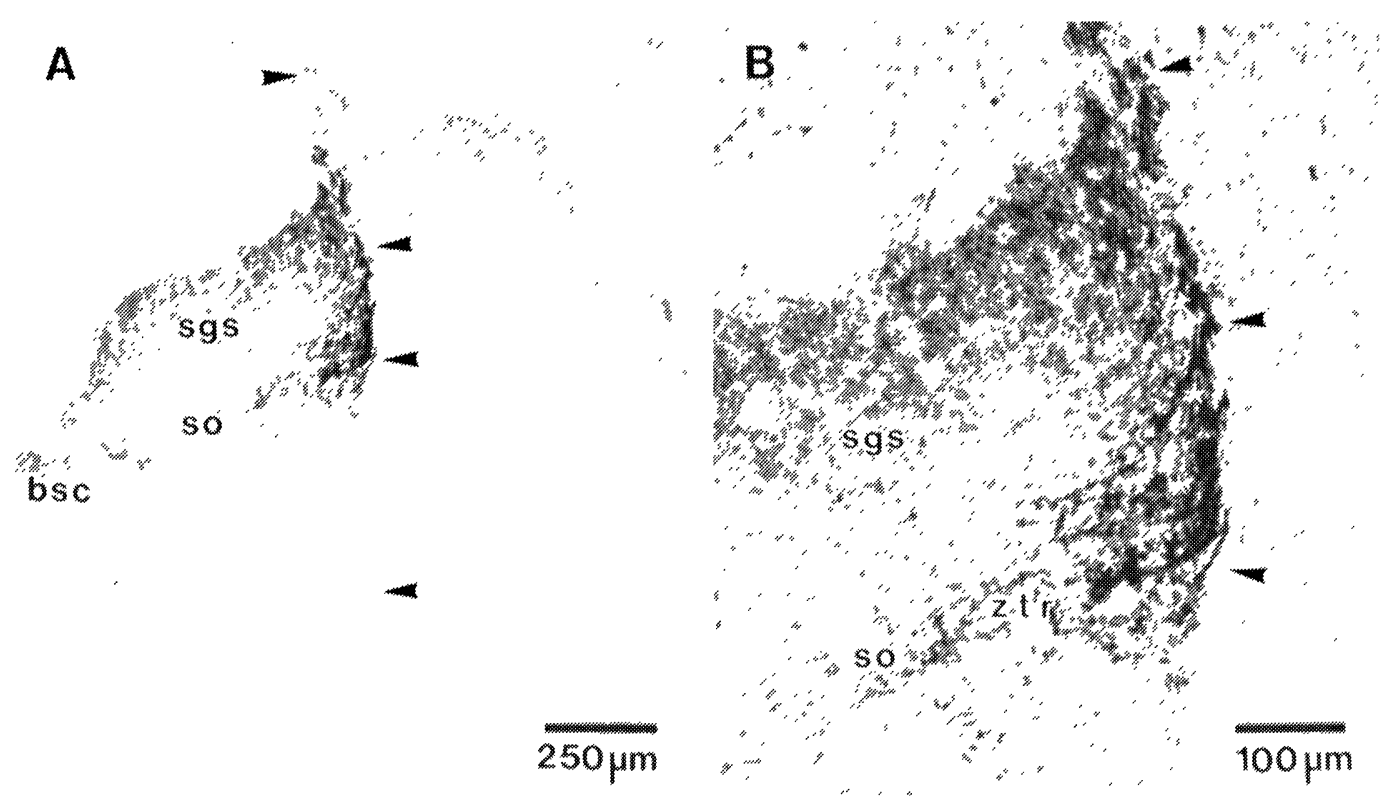

Fig. 7: Optic layers 90 days after transverse knife lesion, sagittal section, contralateral intraocular HRP injection, TMB histochemistry, thionin counterstain. A. Only a thin glial scar remains at the lesion site (arrows) delimitiıg an intensely labeled zone of traumatic reaction rostrally and a zone of complete retinal deafferentation caudally. B. Dense fascicles and neuroma-like tangled masses of retinofugal axons $\left(^{*}\right)$ are labeled proximal to the lesion in the zone of traumatic reaction, both in the stratum opticum (so) and the stratum griseum superficialc (sgs).

total area of a transplant's optic layer interface and the volume of the transplant innervated by the retinal afferent projection $(r=-0.44, p<0.01)$. Linear regression analysis also showed no significant correlation between the volume of transplant innervated by the host retinofugal projection and either the volume of the transplant $(r=0.29, p<0.01)$ or the volume of the optic layers replaced by the transplant $(\mathrm{r}=0.32, \mathrm{p}<0.01)$.

\section{DISCUSSION}

Retinal afferent ingrowth to neocortical transplants in the superior colliculus could not have been due to developmental elongation of host axons, a process largely responsible for afferent ingrowth to transplants in neonatal hosts $/ 8,9,10,15,43,52,59,68,78,83,97 /$, since 4 month old animals were used as hosts in this study and retinofugal axons have completed their growth by the end of the second postnatal week $/ 12,62,90 /$. The observed ingrowth therefore must have resulted from either the sprouting of intact retinofugal axons in the immediate vicinity of the transplant interface or the regenerative growth of retinofugal axons damaged at the transplantation site. Neither the appearance nor the topography of the retinal afferent projections to the transplants were consistent with generalized sprouting from intact retinofugal axons at or near the transplant interface. The sprouting hypothesis, that the magnitude of ingrowth is a function of the total transplant/optic layer interface area, was not supported by our observations. There was no correlation between the total area of the transplant's optic layer interface and the interface area across which retinal afferents penetrated into the transplants. Retinal afferents did not penetrate evenly across the entire transplantoptic layer interface since ingrowth occurred only across small portions of the optic layer interface, 

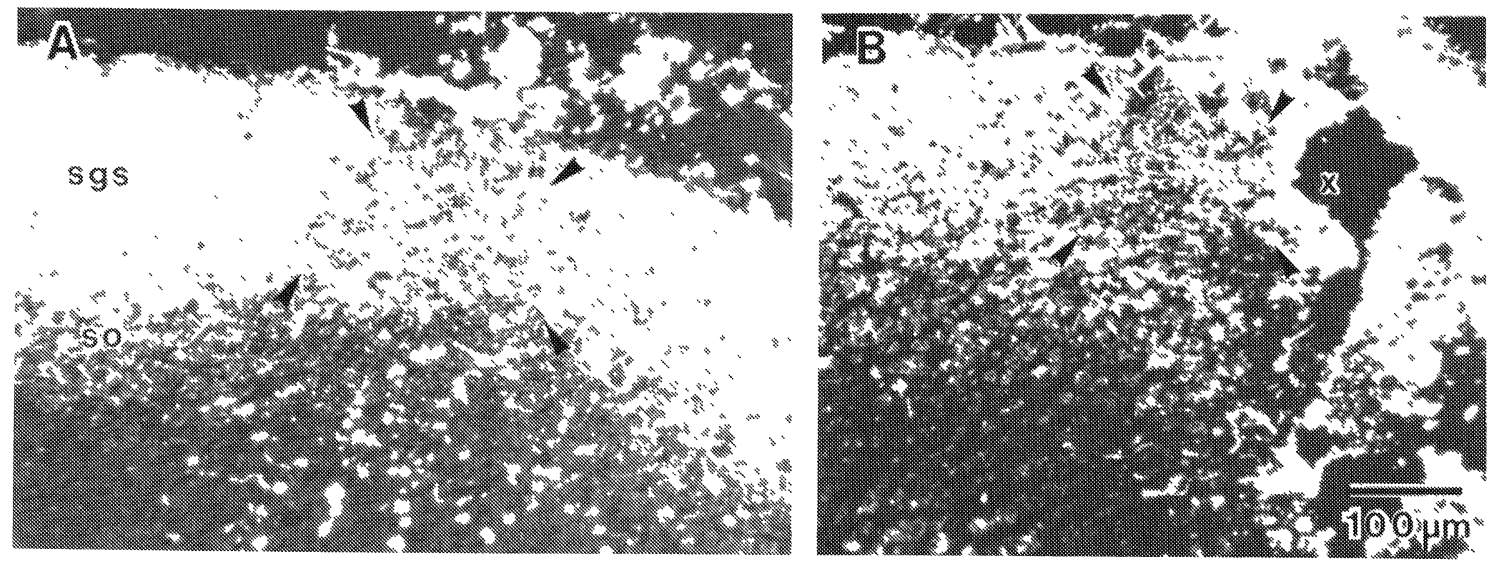

Fig. 8: Zones of partial retinal deafferentation, 1 day after injury, contralateral intraocular HRP injection, TMB histochemistry, polarized light optics. A. Zone of partial retinal deafferentation, delimited by arrows, in the sgs caudal to a transplantation needle lesion. B. Zone of partial retinal deafferentation, delimited by arrows, in the sgs medial to a sagittal tectal slit $(\mathrm{x})$.

$3 \%$ and $7 \%$ in the SXTRT and TRT groups, respectively. Areas of optic layer interface across which retinal afferents penetrated corresponded in every case to the zone of traumatic reaction, and the bulk of the optic layer interface, $97 \%$ and $93 \%$ respectively, was totally devoid of retinal afferent penetration. Despite the fact that transplants in the transverse lesion/transplantation group (TXTRT) had smaller total optic layer interface areas, only $70 \%$ of this interface was devoid of retinal afferent penetration and these transplants received retinal afferent projections which were significantly greater in volume than those seen in the other groups. These results clearly do not support the interpretation that retinal afferent ingrowth to neocortical transplants was due to sprouting of intact retinofugal axons or axon terminals. This conclusion is consistent with those of numerous studies suggesting that sprouting of intact axons in the adult mammalian retinofugal projection in response to local deafferentation, if it occurs at all, is at most limited to a very local and restricted expansion within the normal terminal regions of the retinofugal projection and not the robust neuroplastic response which characterizes the developing retinofugal projection $14,30,36,38,39,41,47,54,55$, $61,69,85,94,95,110,111,117 /$. Similarly, the fact that optic layer innervation patterns did not change qualitatively between 1 day and 1 year after deafferentation following either tectal slits or transection of the optic tract/brachium /101,102, $103,108 /$ is also consistent with the absence of extensive terminal sprouting of spared retinal axon terminals in the superior colliculus $/ 115 /$.

The results of this study very strongly suggest that retinal ganglion cells express an intrinsic regenerative capacity following axonal injury in the optic layers of the superior colliculus. Dense fascicles of intensely HRP labeled retinofugal axons were evident extending up to the wound margin of the zone of traumatic reaction in the stratum opticum 30-90 days after injury. Many of these fascicles were continuous with intensely HRP labeled tangled masses of axons in the stratum opticum and stratum griseum superficiale proximal to the lesion scar. Following optic tract or brachium transection similar neuroma-like neoformations within the zone of traumatic reaction persist for up to one year and increase in size with time $/ 103,108 /$. Axonal neoformations that persist following adult retinofugal axon injury appear to be analogous to the non-myelinated "tangled mass" central neuromas reported by Sung /121/ in the brainstem and spinal cord of humans associated with lesions of 

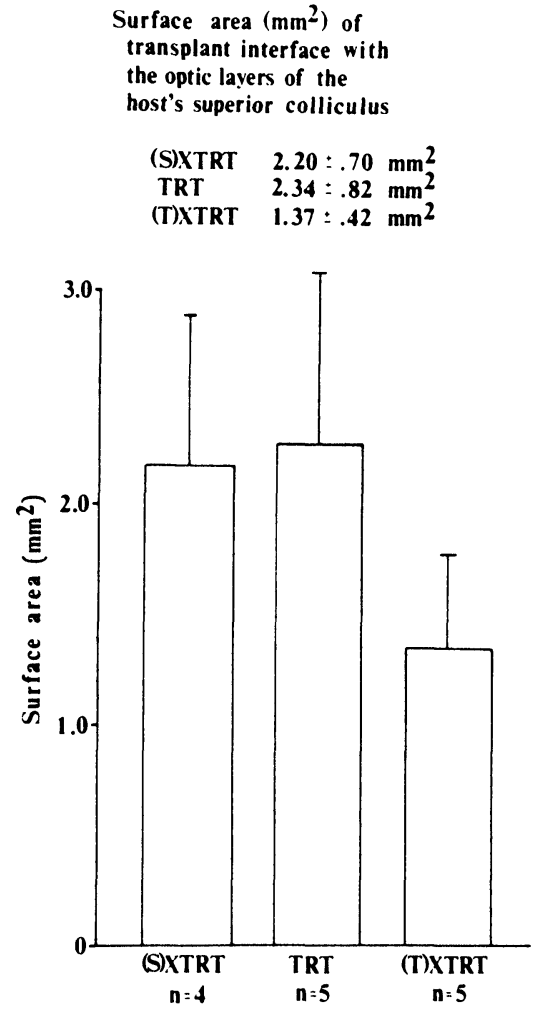

Fig. 9: Quantitative analysis of the surface area of transplant interface with the optic layers in lesion/transplant groups, mean and standard deviation (S.D.) given. The mean area of transplant/optic layer interface in SXTRT cases was not significantly different than that in seen in the TRT group $(p>0.50)$. The total optic layer interface area in the TXTRT group was significantly less than that seen in the in the TRT group $(p<0.05)$ but was not significantly less than that seen in the SXTRT group $(\mathrm{p}<0.10)$.

long standing. Ramon y Cajal in 1928 /96/ described transient regenerative attempts in a "metamorphic" zone of traumatic reaction in the proximal stump of damaged CNS tracts, analogous to the zone seen in the proximal stump of transected peripheral nerves. Our results clearly indicate that the regenerative process within the zone of traumatic reaction in the optic tract, brachium or stratum opticum of the superior colliculus is sustained beyond the initial phase of transient sprouting. Regenerating retinofugal axons may meet a formidable barrier to elongative growth at the scar or within the zone of traumatic reaction that does not stop axonal elongation but does restrict axonal growth to the confines of the zone itself. This phenomenon of sustained, non-directed axonal elongation may be analogous to neuroma formation following severe peripheral nerve damage $/ 120 /$ and the formation of Probst bundles in the cerebral cortex of congenitally acallosal mammals, including humans, $/ 66,88,114$, $132,135 /$ or following damage of the interhemispheric callosal glial "sling" in utero $/ 113,114 /$. These phenomena all have in common continued axonal growth in the absence of the highly organized matrix that they normally grow in or on. Similarly, when damaged brain surfaces did not heal with a thin scar at sites of optic tract or brachium transection, sustained axonal regeneration was expressed in the growth of dense retinofugal axon fascicles on connective tissue elements within the lumen of the resulting lesion cavities which became more pronounced between 1 month and 1 year after injury. A similar but much less vigorous response has been reported following neonatal injury of the optic tract or brachium $/ 26,42,45 /$, apparently reflecting the relatively extensive retrograde degeneration of retinal ganglion cells that occurs following transection of developing retinofugal axons $/ 44,85 /$. There was no indication in any cases from this study or in any cases from our studies of brachium or optic tract transection without transplantation $/ 103,108 /$ that regenerating axons either penetrated through the thin scar that formed at the sites of tectal or diencephalic slits or spontaneously coursed around the lesion margins $132 /$.

The results of this study strongly suggest that when the process of scar formation is supplanted by anatomical integration of embryonic neural tissue with the adult host's optic layers, the regenerative capacity of damaged axons within the zone of traumatic reaction may be expressed as retinal afferent ingrowth. The high correlation between the cross sectional area of the zone of traumatic reaction at the rostral margin of the lesion cavity and the volume of optic layers deafferented $(r=0.85)$ suggests that the area of the $\mathrm{ztr}$ is a useful index of the magnitude of retinofugal axon damage. Since 
A

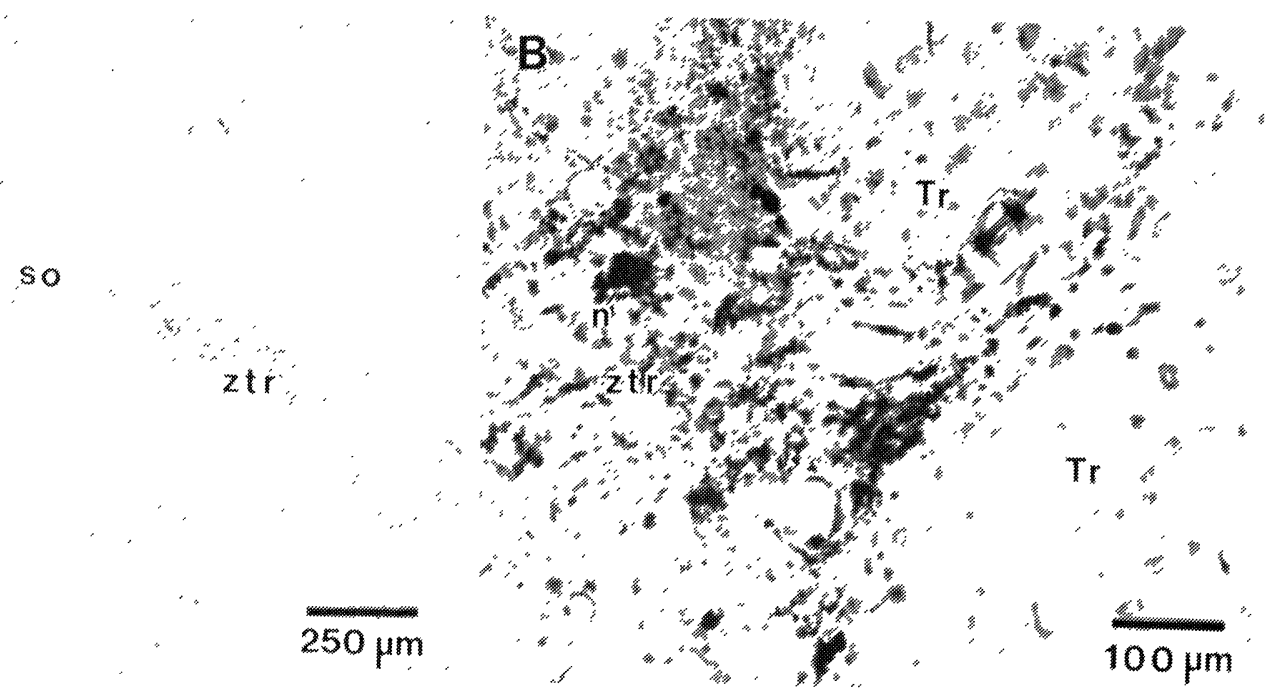

Fig. 10: Zone of traumatic reaction rostral to transplants in the superior colliculus, 30-90 days after lesion/transplantation surgery. contralateral intraocular HRP injection. TMB histochemistry, thionin counterstain. A. Intensely labeled retinofugal fibers in the small zone of traumatic reaction rostral to a transplant, 30 days after lesion/TRT surgery. B. Small neuroma-like tangled masses of HRP labeled retinofugal fibers (n) are present in the ztr proximal to a region of apparently well integrated interface where blood vessels are present, 90 days after transverse lesion/transplant surgery.

the optic layer interface area across which retinal afferents penetrated corresponded in every case to the zone of traumatic reaction in the optic layers, the highly significant $(r=0.92)$ positive correlation between this interface area and the volume of transplant innervation indicates that the magnitude of retinal afferent ingrowth was highly dependent upon the magnitude of retinofugal axonal damage at the transplantation site. Injury of progressively larger populations of retinofugal axons in the optic layers yielded correspondingly larger interface areas with retinal afferent penetration and resulted in proportionately larger volumes of transplant retinal afferent innervation. Analysis of the topography of retinal afferent ingrowth across transplant optic layer interface regions confirmed the hypothesis that ingrowth arose only from regions where retinofugal axons were damaged, the zone of traumatic reaction. Although the volume of retinal afferent ingrowth to the transplants was highly correlated with the volume of retinal deafferentation in the optic layers of lesion control animals for all three lesion/transplantation groups, the volume of the retinal afferent projection represented only from $5.1 \%$ to $16.8 \%$ of the volume of optic layers deafferented. The presence of thick, dense, darkly labeled fascicles and neuroma-like tangled masses of axons in the zone of traumatic reaction proximal to the transplant suggests that not all the damaged axons contributed to the transplant's retinal afferent projection. As Brasko and Das /7/ have shown, the neuropil of developing transplants is not homogeneous and regions of dense intratransplant fiber aggregation may be refractory to afferent ingrowth. Under these conditions regenerating fibers may not enter heterotopic transplants but may, instead, form neuroma-like structures proximal to the interface. Based upon these observations and correlations we conclude that the retinal afferent ingrowth to the neocortical transplants was due to the regeneration of damaged axons.

Frost $/ 33,34 /$ demonstrated that, in the absence of normal retino-recipient zones, developing retinal axons will form synapses in deafferented thalamic auditory and somatosensory regions that are not normally retino-recipient. Similarly, retinofugal 

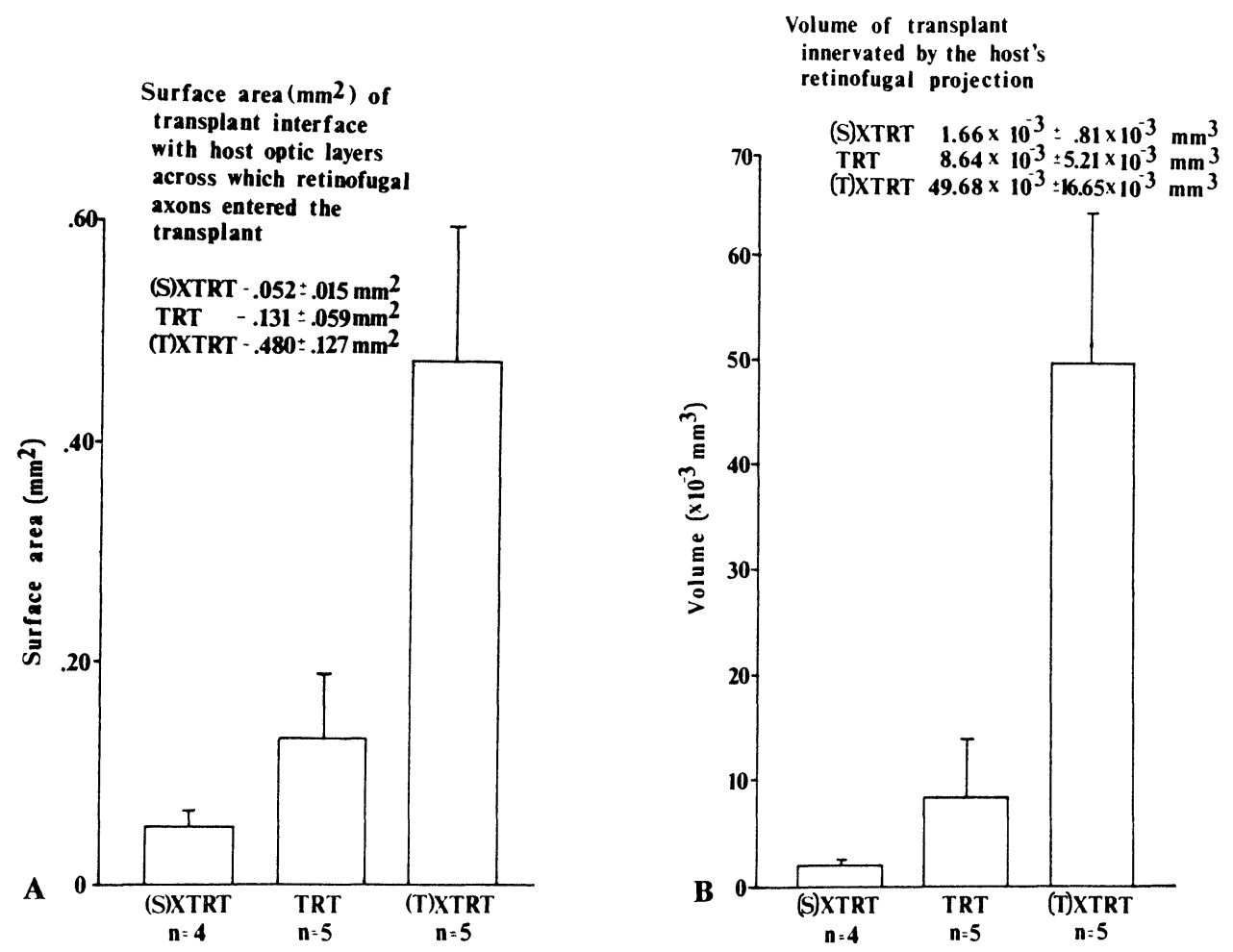

Fig. 11: Quantitative analysis of regions associated with different lesion/transplantation conditions. A. Comparison of the surface area of transplant optic layer interface across which retinal afferents entered transplants, the "effective" interface area with the ztr, mean and standard deviation (S.D.) given. The mean area of effective interface with TRT transplants was significantly greater than the effective interface area in the SXTRT group $(p<0.01)$. The mean effective interface area in the TXTRT group was significantly greater than either the corresponding areas in the TRT or SXTRT groups $(p<0.001)$. B. Comparison of the volume of transplants innervated by the host retinofugal projection in lesion/transplant groups, mean and standard deviation (S.D.) given. The volume of transplant parenchyma innervated in the SXTRT group was significantly less than that seen in the TRT group $(p<0.05)$. The volume of the retinal afferent projections to TXTRT cases was significantly greater than those in either the SXTRT or TRT groups $(p<0.001$ and $\mathrm{p}<0.01$, respectively).

axons regenerating through peripheral nerve grafts may form synapses either upon neurons in their appropriate target regions of the superior colliculus $/ 14,127 /$ or with inappropriate targets such as the cerebellum /138/. Aberrant retino-thalamic and retino-cerebellar projections, like the aberrant retino-cortical projections in the present study, are "non-specific" in the sense that these targets do not normally receive a retinal afferent projection in vivo. The suggestion that "appropriate" post synaptic targets found in regions that normally receive retinal afferent projections are required for retinal innervation, does not absolutely hold. However, because an excitatory amino acid, such as glutamate, may be used as the neurotransmitter for the major excitatory afferent systems to the superior colliculus, specific thalamic relay nuclei, neocortex, and cerebellum $/ 76 /$, this apparent non-specific innervation pattern may reflect a short distance recognition of analogous, if not wholly "appropriate", glutamatergically receptive post synaptic targets.

Ramon y Cajal /96/ suggested that damaged adult mammalian retinal ganglion cells mounted only an abortive attempt at regeneration following axonal injury. Prior to the time our studies were 
A

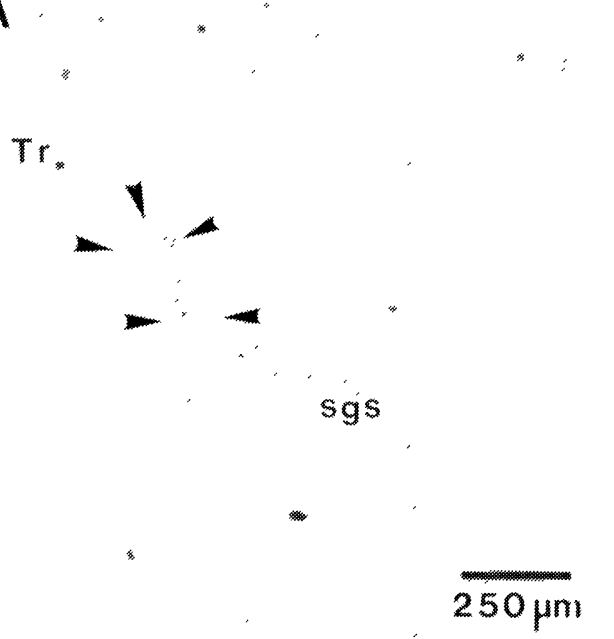

B

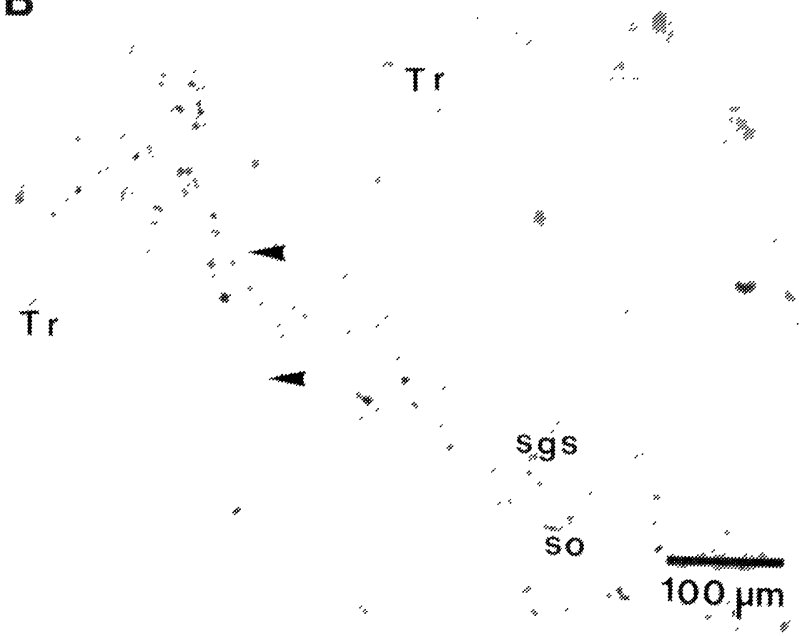

Fig. 12: Retinal afferents to a neocortical transplant (TRT group), 90 days after transplantation, contralateral intraocular HRP injection, TMB histochemistry, thionin counterstain. A. HRP labeled retinofugal axons penetrate $\sim 150 \mu \mathrm{m}$ into the transplant parenchyma from a lateral interface region with the host's optic layers. B. Detail of (A) showing pattern of HRP terminal labeling in a neuron dense region of the transplant.

conducted (1980-1983), very few studies suggested otherwise $132,37,75 /$, and none of these demonstrated sustained axonal regeneration that was unequivocally due to injury of positively identified retinal ganglion cells. Our observations of retinofugal axon regeneration in adult mammals in vivo /101-104,108/ have been subsequently confirmed in several studies. Transection of the brachium of the superior colliculus in adults also results in regenerative axonal growth into the lesion cavity $/ 45,103,108 /$ or the regenerative growth of axons into $/ 45,100,103,104,108 /$ or through /101$103,108 /$ embryonic neural tissues or into peripheral nerve grafts $/ 118 /$ transplanted at the transection site. Although the vast majority of retinal ganglion cells succumb to retrograde degeneration following optic nerve transection $/ 2,5,27,40,63,71,73,79,86$, $99,107,123,124,128 /$ a small $(5-10 \%)$ population does survive and may express a regenerative capacity as ingrowth to peripheral nerve grafts $13,14,31,35,109,116,122,123,126,127,129,130,134$, 138 / or transplants of embryonic neural tissue /112/. The cellular mechanisms responsible for the ability of retinal ganglion cells to withstand axotomy and regenerate following injury at the level of the optic tract, brachium or stratum opticum and the relative inability of the same neurons to survive injury and their meager regenerative efforts following injury at the level of the optic nerve are poorly understood. Resolution of this paradox may provide insight that will lead to greater afferent innervation of transplants in adults by fiber systems that are more refractory to regrowth following injury.

\section{ACKNOWLEDGMENTS}

This work was performed in the course of doctoral research at Purdue University (DTR) and portions were presented at the 96th Session of the American Association of Anatomists Annual Meeting in Atlanta, GA on 6 April 1983 and at a satellite symposium of the 13th Annual Meeting of the Society for Neuroscience in Boston, MA on 5 November 1983. The many helpful suggestions from my graduate committee, Dr. Jacob E. Wiebers, Dr. Edward J. Hinsman and particularly my committee chairman, Dr. Joseph A. Altman are gratefully acknowledged. I would especially like to 
thank Doreen Ross for her multiple processings of these words and Dr. Jane Brasko for her insightful comments on the manuscript and its proofreading. This work was supported by NIH grant NS08817(GDD), NS 28852 (DTR) and NS-08803.
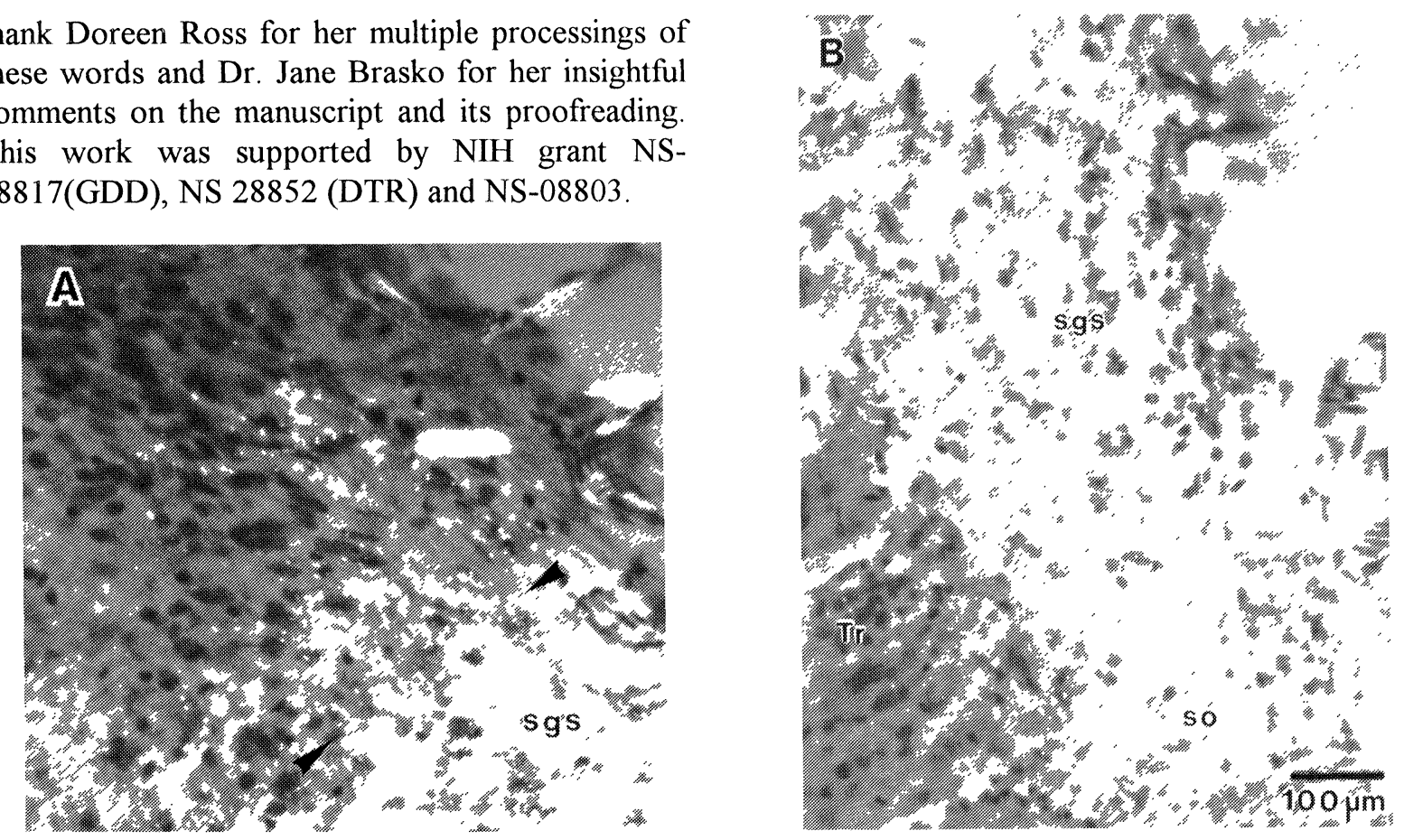

Fig. 13: Retinal afferent projection and zone of traumatic reaction associated with sagittal lesion/ transplantation (SXTRT), 90 days after surgery, contralateral intraocular HRP injection, TMB histochemistry, polarized light optics. A. Retinal afferents penetrate $\sim 150 \mu \mathrm{m}$ into the transplant parenchyma across a lateral interface with the zone of traumatic reaction in the hosts optic layers. B. Distention of the optic layer lateral to a transplant; note the presence of a few swollen axons and axons capped with terminal clubs.

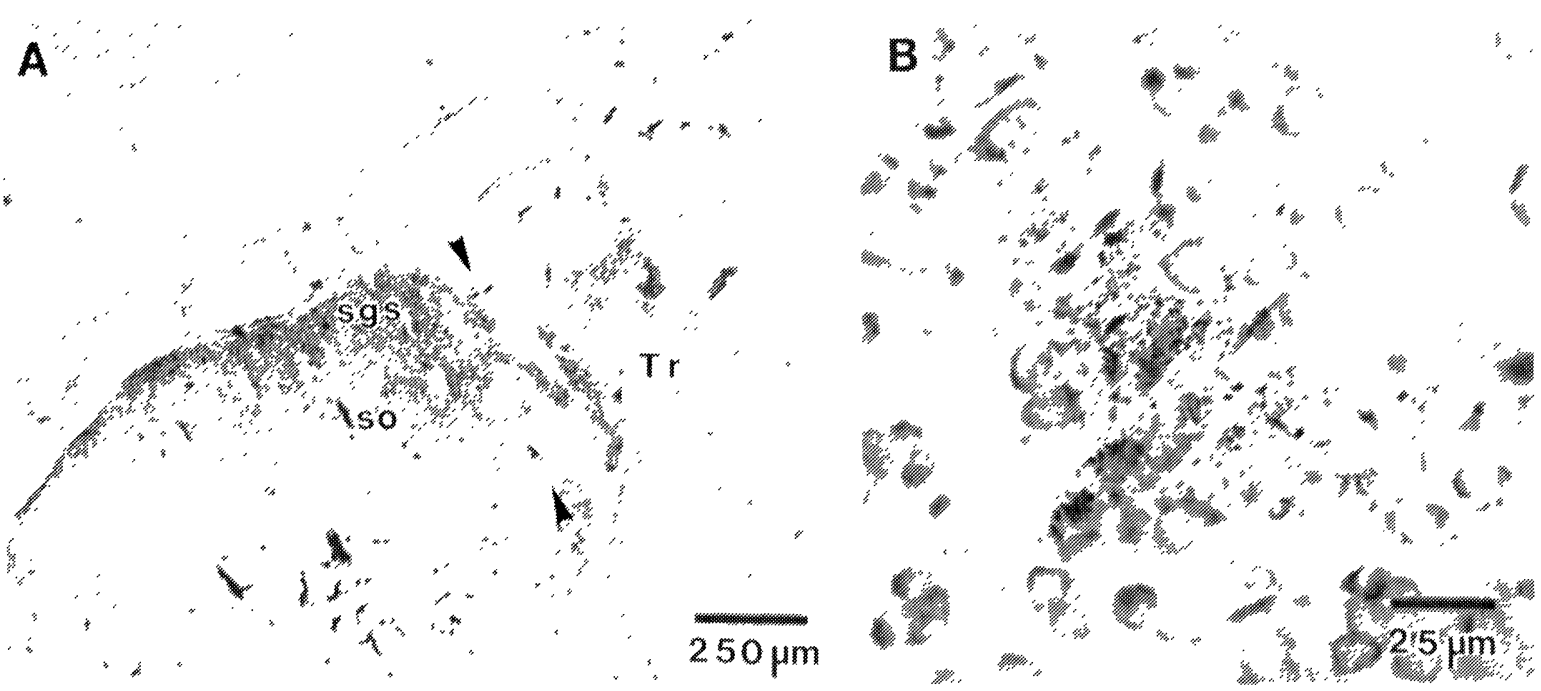

Fig. 14: Retinal afferent projection into a neocortical transplant (TXTRT group), 90 days after transverse lesion/transplantation surgery, contralateral intraocular HRP injection, TMB histochemistry, thionin counterstain. A. Numerous dense and sparse patches of HRP terminal labeling are present as far as $500 \mu \mathrm{m}$ from the interface within the transplant parenchyma. B. Detail of terminal labeling in a neocortical neuron dense region of the transplant parenchyma $400 \mu \mathrm{m}$ from the interface. 


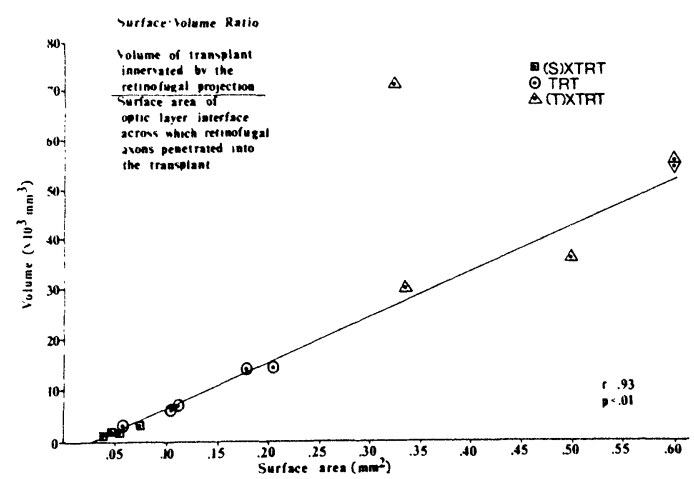

Fig. 15: Scattergram plot of surface volume relationships: correlation of the volume of the transplant innervated with the area of the transplant's interface with the zone of traumatic reaction for all cases in TRT, SXTRT and TXTRT groups.

\section{REFERENCES}

1. Adams JC. Stabilizing and rapid thionin staining of TMB based reaction product. Neurosci Lett 1980; 17: 7-9.

2. Alcutt $D$, Berry $M$, Sievers J. A quantitative comparison of the reactions of retinal ganglion cells to optic nerve crush in neonatal and adult mice. Dev Brain Res 1984; 16: 231-240.

3. Bähr M, Eschweiler GW, Wolberg H. Precrushed sciatic nerve grafts enhance the survival and axonal regrowth of retinal ganglion cells in adult rats. Exp Neurol 1992; 116: 13-22.

4. Baisden RH, Chen CL. Sprouting of ipsilateral retinal projections in the optic system of the albino rat. Exp Neurol 1978; 61: 549-560.

5. Barron $\mathrm{KD}$, McGuiness CM, Misatone LJ, Zanakis MF, Grafstein B, Murray MM. RNA content of normal and axotomized retinal ganglion cells of rat and goldfish. J Comp Neurol 1985; 236: 265-273.

6. Barron KD. Comparative observations on the cytologic reactions of central and peripheral nerve cells to axotomy. In: Kao CC, Bunge RP, and Reier PJ, eds, Spinal Cord Reconstruction. New York: Raven Press, 1983; 7-40.

7. Brasko J, Das GD. Developmental events that influence afferent ingrowth to neocortical transplants in the cerebellum of adult rats. Ph.D. Thesis, Purdue Univ., West Lafayette, IN.

8. Bregman BS, Bernstein-Goral $\mathrm{H}$. Both regenerating and late-developing pathways contribute to transplantinduced anatomical plasticity after spinal cord lesions at birth. Exp Neurol 1991; 112: 49-63.
9. Bregman BS, Kunkel-Bagden E, McAtee M, O’Neill A. Extension of the critical period for developmental plasticity of the corticospinal pathway. J Comp Neurol 1989; 282: 355-370.

10. Bregman BS, Kunkel-Bagden E. Effect of target and non-target transplants on neuronal survival and axonal elongation after injury to the developing spinal cord. Prog Brain Res 1988; 78: 205-211.

11. Brodal A. Modification of Gudden's method for study of cerebral localization. Arch Neurol Psychiat 1940; 43-46-58.

12. Bunt SM, Lund RD, Land PW. Prenatal development of the optic projection in albino and hooded rats. Dev Brain Res 1983; 6: 149-168.

13. Campbell $\mathrm{K}$, Kalon $\mathrm{P}$, Wictorin $\mathrm{K}$, Lundberg $\mathrm{C}$, Mandel RJ. Characterization of GABA release from intrastriatal striatal transplants: dependence on hostderived afferents. Neuroscience 1993; 53: 403-415.

14. Carter DA, Bray GM, Aguayo AJ. Regenerated retinal ganglion cell axons can form well differentiated synapses in the superior colliculus of adult hamsters. J Neurosci 1989; 9: 4042-4050.

15. Castro AJ, Tonder N, Sunde NA, Zimmer J. Fetal cortical transplants in the cerebral hemisphere of newborn rats: a retrograde fluorescent analysis of connections. Exp Brain Res 1987; 66: 533-542.

16. Cheng CL, Povlishock JT. The effect of traumatic brain injury on the visual system: a morphologic characterization of reactive axonal change. J Neurotrauma 1988 ; 5: 47-60.

17. Cotman CW, Lynch GS. Reactive synaptogenesis in the adult nervous system: the effects of partial deafferentation on new synapse formation. In: $S$ Barondes ed, Neuronal Recognition. New York: Plenum Press, 1976; 69-108.

18. Das GD, Altman JA. Studies on the transplantation of developing neural tissue in the mammalian brain: I Transplantation of cerebellar slabs into the cerebellum of neonate rats. Brain Res 1972; 38: 233-249.

19. Das GD, Altman JA. The fate of transplanted precursors of nerve cells in the cerebellum of young rats. Science 1971; 173: 637-638.

20. Das GD, Hallas BH. Transplantation of neural tissue in the brain of adult rat. Experientia 1978; 34: 13041306.

21. Das GD, Ross DT. Stereotaxic technique for transplantation of neural tissues in the brain of adult rats. Experientia 1982; 38: 848-850.

22. Das GD. Transplantation of embryonic neural tissue in the mammalian brain: I growth and differentiation of neuroblasts from various regions of the embryonic brain in the cerebellum of neonate rats. TIT J Life Sci 1974; 4: 93-124.

23. Defontaines B, Peschanski M, Onteniente B. Host dopaminergic afferents affect the development of DARPP-32 immunoreactivity in transplanted 
embryonic striatal neurons. Neuroscience 1992; 48: 857-869.

24. Doucet G, Murata Y, Brundin P, Bosler O, Mons N, Geffard M, Ouimet CC, Björklund A. Host afferents into intrastriatal transplants of fetal ventral mesencephalon. Exp Neurol 1989; 106: 1-19.

25. Dunn-Meynell AA, Levin BE. Fetal neocortical transplants into the medial forebrain bundle attract ingrowth of catecholaminergic fibers in adult rat brain. Exp Neurol 1991; 111: 217-227.

26. Dyson SE, Harvey, AR, Trapp BD, Heath, JW. Ultrastructural and immunohistochemical analysis of axonal regrowth and myelination in membranes which form over lesion sites in the rat visual system. J Neurocytol 1988; 17: 797-808.

27. Eayrs JT. Relationship between the ganglion cell layer of the retina and the optic nerve in the rat. $\mathrm{Br} J$ Opthalmol 1952; 36: 453-459.

28. Ebner FF, Erzurumlu RS, Lee SM. Peripheral nerve damage facilitates functional innervation of brain grafts in adult sensory cortex. Proc Natl Acad Sci USA 1989; 86: 730-734.

29. Erzurumlu RS, Ebner FF. Peripheral nerve transection induces innervation of embryonic neocortical transplants by specific thalamic fibers in adult mice. $J$ Comp Neurol 1988; 272: 536-544.

30. Eysel UT, Gonzalez-Aguillar F, Mayer U. Reorganization of retinogeniculate connections after retinal lesions in the adult cat In: Flohr H, Precht W, eds, Lesion Induced Plasticity in Sensorimotor Systems. New York: Springer-Verlag, 1981; 339-350.

31. Eysel UT, Peichl L. Regenerative capacity of retinal axons in the cat rabbit and guinea pig. Exp Neurol 1985; 88: 757-766.

32. Foerster AP. Spontaneous regeneration of cut axons in adult rat brain. J Comp Neurol 1982; 210: 335-356.

33. Frost DO. Development of anomalous retinal projections to non-visual thalamic nuclei in Syrian hamsters: a quantitative study. J Comp Neurol 1986; 252: 95-105.

34. Frost DO. Orderly anomalous retinal projections to the medial geniculate ventrobasal and lateral posterior nuclei of the hamster. J Comp Neurol 1981; 203: 227 256.

35. Fukuda Y, Sasaki H, Adachi E, Inoue T, and Morigiwa $\mathrm{K}$. Optic nerve regeneration by peripheral nerve transplant. Neurosci Res (Suppl) 1990; 13: S24-30.

36. Garraghty PE, Sur M, Weller RE, Sherman SM. Morphology of retinogeniculate $\mathrm{X}$ and $\mathrm{Y}$ axon arbors in monocularly enucleated cats. J Comp Neurol 1986; 251: 198-215.

37. Goldberg S, Frank B. Will the central nervous system in the adult mammal regenerate after bypassing a lesion? A study in the mouse and chick visual system. Exp Neurol 1980;70: 675-689.
38. Goodman DC, Bogdasarian RS, Horel JA. Axonal sprouting of the ipsilateral optic tract following opposite eye removal. Brain Behav Evol 1973; 8: 2750.

39. Goodman DC, Horel JA. Sprouting of optic tract projections in the brainstem of the rat. J Comp Neurol 1966; 127: 71-78.

40. Grafstein B, Ingoglia NA. Intracranial transection of the optic nerve in adult mice: preliminary observations. Exp Neurol 1982; 76: 318-330.

41. Guillery RW. Experiments to determine whether retinogeniculate axons can form translaminar collateral sprouts in the dorsal lateral geniculate nucleus of the cat. J Comp Neurol 1972; 146: 407-420.

42. Harvey AR, Gan SK, Pauken JM. Fetal tectal or cortical tissue transplanted into brachial lesion cavities in rats: influence on the regrowth of host retinal axons. J Comp Neurol 1987; 263: 126-136.

43. Harvey AR, Lund RD. Transplantation of tectal tissues in rats II. Distribution of host neurons which project to transplants. J Comp Neurol 1981; 202: 505-520.

44. Harvey AR, Robertson D. Time course and extent of retinal ganglion cell death following ablation of the superior colliculus in neonatal rats. J Comp Neurol 1992; 325: 83-94.

45. Harvey AR, Tan MM. Spontaneous regeneration of adult rat retinal ganglion cell axons in vivo. NeuroReport 1992; 3: 239-242.

46. Hess D, Schneider GE. Advantages of polarization microscopy in horseradish peroxidase neurohistochemistry. J Histochem Cytochem 1981; 29: 14481450.

47. Hickey TL. Translaminar growth of axons in the kitten dorsal lateral geniculate following removal of one eye. J Comp Neurol 1975; 161: 359-382.

48. Höhmann CF, Ebner FF. Basal forebrain lesions facilitate adult host fiber ingrowth into neocortical transplants. Brain Res 1988; 448: 53-66.

49. Houle JD, Reier PJ. Regrowth of calcitonin gene related peptide (CGRP) immunoreactive axons from the chronically injured spinal cord into fetal spinal cord tissue transplants. Neurosci Lett 1989; 103: 253258.

50. Illing B, Wassle $H$. Visualization of the HRP reaction product using the polarization microscope. Neurosci Lett 1979; 13: 7-10.

51. Itoh Y, Tessler A. Regeneration of adult dorsal root axons into transplants of fetal spinal cord and brain: a comparison of growth and synapse formation in appropriate and inappropriate targets. J Comp Neurol $1990 ; 302: 272-293$.

52. Jaeger CB, Lund RD. Transplantation of embryonic occipital cortex to the tectal region of newborn rats: a light microscopic study of organization and connectivity of the transplants. J Comp Neurol 1980; 194: 571-597. 
53. Jakeman LB, Reier PJ. Axonal projections between fetal spinal cord transplants and the adult rat spinal cord: a neuroanatomical tracing study of local interactions. J Comp Neurol 1991; 307: 311-334.

54. Jen LS, Cheung YM, Chow KL. The origin and terminal arbors of individual uncrossed retinogeniculate fibers in rabbits. Neuroscience 1989; 29: 479-493.

55. Kalil RE. Formation of new retino-geniculate connections in kittens after removal of one eye. Anat Rec 1972; 172: 339-340.

56. Kalil K, Schneider GE. Retrograde cortical and axonal changes following lesions of the pyramidal tract. Brain Res 1975; 89: 15-27.

57. Kromer LF, Björklund A, Stenevi U. Innervation of embryonic hippocampal implants by regenerating axons of cholinergic septal neurons in the adult rat. Brain Res 1981; 210: 153-171.

58. Kromer LF, Björklund A, Stenevi U. Regeneration of the septohippocampal pathways in adult rats is promoted by utilizing embryonic hippocampal implants as bridges. Brain Res 1981; 210: 173-200.

59. Kurotani T, Yamamoto N, Toyama K. Development of neural connections between visual cortex and transplanted lateral geniculate nucleus in rats. Dev Brain Res 1993; 71: 151-168.

60. Labandeira-Garcia JL, Wictorin K, Cunningham ET, Björklund A. Development of intrastriatal striatal grafts and their afferent innervation from the host. Neuroscience 1991; 42: 407-426.

61. Labar DR, Berman NE, Murphy EH. Short and long term effects of neonatal and adult visual cortex lesions on the retinal projection to the pulvinar in cats. J Comp Neurol 1981; 197: 639-659.

62. Land PW, Lund RD. Development of the rat's uncrossed retinotectal pathway and its relation to plasticity studies. Science 1979; 205: 698-700.

63. Leinfelder PJ. Retrograde degeneration in the optic nerves and retinal ganglion cells. Trans Am Opthalmol Soc 1938; 36: 307-318.

64. Liu FC, Dunnett SB, Graybiel AM. Influence of mesostriatal afferents on the development and transmitter regulation of intrastriatal grafts derived from embryonic striatal primordia. J Neurosci 1992; 12: 4281-4297.

65. Liu FC, Graybiel AM, Dunnett SB, Baughman RW. Intrastriatal grafts derived from fetal striatal primordia: II. Reconstitution of cholinergic and dopaminergic systems. J Comp Neurol 1990; 295: 114.

66. Loeser JD, Alvord EC. Agenesis of the corpus callosum. Brain 1968; 91: 533-546.

67. Lund RD, Harvey AR. Transplantation of tectal tissue in rats I. Organization of transplants and pattern of distribution of host afferents within them. J Comp Neurol 1983; 201: 191-209.
68. Lund RD, Hauschka SD. Transplanted neural tissue develops connections with host rat brain. Science 1976; 193: 583-584.

69. Lund RD, Lund JS. Synaptic adjustment after deafferentation of the superior colliculus of the rat. J Comp Neurol 1971; 171: 804-807.

70. Lynch GS, Stanfield B, Cotman CW. Developmental differences in post lesion axonal growth in the hippocampus. Brain Res 1973; 59: 155-168.

71. Madison R, Moore MR, Sidman RL. Retinal ganglion cells and axons survive optic nerve transection. Int $\mathrm{J}$ Neurosci 1984; 23: 15-32.

72. Majda BT, Harvey AR. Tectal tissue grafted to the midbrain of newborn rats: effect of donor age on the survival, growth and connectivity of transplants. J Neural Transplant 1989; 1: 95-103.

73. Mantz J, Klein M. Recherche experimentales sur la section et la ligature du nerf optique chez le rat. Comp Rend Soc Biol Paris 1951; 145: 920-924.

74. Matthews DA, Cotman CW, Lynch GS. An electron microscopic study of lesion induced synaptogenesis in the dentate gyrus of the adult rat: I Magnitude and time course of deafferentation. Brain Res 1976; 115: 121.

75. McConnell P, Berry M. Regeneration of retinal ganglion cell axons in the adult mouse retina. Brain Res 1982; 241: 362-365.

76. McGeer PL, Eccles JC, McGeer EG. Molecular Neurobiology of the Mammalian Brain, 2nd ed. New York: Plenum Press, 1987.

77. Mesulam M-M. Tetramethyl benzadine for horseradish peroxidase neurohistochemistry: a non-carcinogenic blue reaction product with superior sensitivity for visualizing neural afferents and efferents. J Histochem Cytochem 1978; 26: 106-117.

78. McLoon SC, Lund RD. Development of fetal retina, tectum, and cortex transplanted to the superior colliculus of adult rats. J Comp Neurol 1983; 217: 376389.

79. Misatone LJ, Gerschenbaum M, Murray MM. Viability of retinal ganglion cells after optic nerve crush in adult rats. J Neurocytol 1984; 13: 449-465.

80. Murray M, Zimmer J, Raisman G. Quantitative electron microscopic evidence for re-innervation in the adult rat interpeduncular nucleus after lesions of the fasciculus retroflexus. J Comp Neurol 1979; 187: 447 468.

81. Nakamura Y, Mizuno N, Konishi A. A quantitative electron microscopic study of cerebellar axon terminals on the magnocellular red nucleus in the cat. Brain Res 1978; 147: 17-27.

82. Oblinger MM, Das GD. Connectivity of neural transplants in adult rats: analysis of afferents and efferents of neocortical transplants in the cerebellar hemisphere. Brain Res 1982; 249: 31-49.

83. Oblinger MM, Hallas BH, Das GD. Neocortical 
transplants in the cerebellum of the rat: their afferents and efferents. Brain Res 1980; 189: 228-232.

84. Park JK, Joh TH, Ebner FF. Tyrosine hydroxylase is expressed by neocortical neurons after transplantation. Proc Natl Acad Sci USA 1986; 7495-7498.

85. Perry VH, Cowey A. Changes in the retinofugal pathways following cortical and tectal lesions in neonatal and adult rats. Exp Brain Res 1979; 35: 97108.

86. Perry VH. Evidence for an amacrine cell system in the ganglion cell layer of the rat retina. Neuroscience 1981; 6: 931-944.

87. Pritzel $M$, Isacson $O$, Brundin $P$, Wiklund $L$, Björklund A. Afferent and efferent connections of striatal grafts implanted into the ibotenic acid lesioned neostriatum in adult rats. Exp Brain Res 1986; 65: 112-126.

88. Probst $M$. Über der Bau des balkenlosen grosshirns Sowle über Mikrogyrie und Heterotopie der grauen Substanz. Arch Psychiat 1901; 34: 709-786.

89. Pruitt JN, Feringa ER, McBride RL. Corticospinal axons persist in cervical and high thoracic regions 10 weeks after a T-9 spinal cord transection. Neurology 1988; 38: 946-950.

90. Raedler A, Seivers J. The development of the visual system of the albino rat. Adv Anat Embryol Cell Biol 1975; 50: 7-88.

91. Raisman G, Ebner FF. Mossy fiber projections into and out of hippocampal transplants. Neuroscience 1984; 4 : 783-801.

92. Raisman G, Field PM. A quantitative investigation of the development of collateral innervation after partial deafferentation of the septal nuclei. Brain Res 1973 50: 241-264.

93. Raisman G. Neuronal plasticity in the septal nuclei of the adult rat. Brain Res 1969; 14: 25-48.

94. Ralston HJ, Chow KL. Synaptic reorganization in the degenerating lateral geniculate nucleus of the rabbit. $\mathrm{J}$ Comp Neurol 1973; 147: 321-350.

95. Ramoa AS, Campbell G, Shatz CJ. Retinal ganglion beta cells project transiently to the superior colliculus during development. Proc Natl Acad Sci USA 1989; 86: 2061-2065.

96. Ramon y Cajal S. Degeneration and Regeneration in the Nervous System Vols I and II (R May, trans). New York: Hafner, 1928.

97. Reier PJ, Bregman BS, Wujek JR. Intraspinal transplantation of embryonic spinal cord tissue in neonatal and adult rats. J Comp Neurol 1986; 247 : 275-296.

98. Reis DJ, Ross RA, Gilad G, Joh TH. Reaction of central catecholaminergic neurons to injury: model systems for studying the neurobiology of central regeneration and sprouting In: $\mathrm{CW}$ Cotman ed, Neuronal Plasticity. New York: Raven Press, 1978; 197-226
99. Richardson PM, Issa VMK, Shemie S. Regeneration and retrograde degeneration of axons in rat optic nerve. J Neurocytol 1982; 11: 949-966.

100. Ross DT, Das GD. Adult rat optic tract axons sprout into neocortical transplants. Anat Rec 1981; 199: $217 \mathrm{~A}$

101. Ross DT, Das GD. Lesion size and position influence the magnitude of retinal afferent ingrowth to neocortical transplants. Anat Rec 1982; 202: 161A.

102. Ross DT, Das GD. Regeneration of axons from the transected optic tract of adult rats into and through neocortical transplants. Soc Neurosci Abst 1982; 8: 758.

103. Ross DT, Das GD. Regenerative growth of retinofugal axons into and through neocortical transplants following transection of the optic tract in adult rats In: Das GD, Wallace RB, eds, Neural Transplantation and Regeneration. New York: Springer-Verlag, 1985; 181227.

104. Ross DT, Das GD. Retinal afferent ingrowth to neocortical transplants in the adult rat superior colliculus is due to the regeneration of damaged axons rather than sprouting from intact axons. Anat Rec 1983; 205: 167A.

105. Ross DT, Ebner FF. Thalamic retrograde degeneration following cortical injury: an excitotoxic process? Neuroscience 1990; 35: 525-550.

106. Ross DT, Ebner FF. Neocortical transplants in the SI cortex of adult mice receive thalamic afferents from the posteromedial (POm) but not the ventrobasal (VB) nucleus. Soc Neurosci Abstr 1985; 11: 974.

107. Ross DT, Tempesti P, McKittrick RE. A comparison of the reaction of adult rat retinal ganglion cells, amacrine cells and Müller glial cells to optic nerve transection or occlusion of the central retinal artery. Anat Rec 1989; 223: 147A.

108. Ross DT. Regenerative growth of adult rat retinofugal axons: traumatic reaction neuroma formation and the regeneration of axons into and through transplants of embryonic neocortical tissue. Ph.D. Thesis, Purdue Univ, West Lafayette IN, 1983.

109. Scalia F, Roca S. Optic nerve regeneration with return of vision through autologous peripheral nerve graft. Brain Res 1992; 585: 318-321.

110. Schneider GE. Is it really better to have your brain lesion early? A revision of the "Kennard Principle." Neuropsychologia 1979; 17: 557-583.

111. Shen CL. Retinofugal sprouting of ipsilateral projections in rat. Proc Natl Sci Counc Repub China [B] 1987; 11: 283-288.

112. Sievers J, Hausmann B, Berry M. Fetal brain grafts promote axon regeneration and survival of adult retinal ganglion cells. Prog Brain Res 1988; 78: 371378.

113. Silver J, Ogawa MY. Postnatally induced formation of 
the corpus callosum in acallosal mice on glia coated cellulose bridges. Science 1983; 220: 1067-1069.

114. Silver J, Lorenz SE, Whalsten D, Coughlin J. Axonal guidance during development of the great cerebral commissures: descriptive and experimental studies in vivo on the role of pre-formed pathways. J Comp Neurol 1982; 127: 435-444.

115. So KF, Schneider GE. Abnormal recrossing retinotectal projections after early lesions in Syrian hamsters: age related effects. Brain Res 1978; 147 : 277-295.

116. So KF, Aguayo AJ. Lengthy regrowth of cut axons from ganglion cells after peripheral nerve transplantation into the retina of adult rats. Brain Res 1985; 328: 349-354.

117. Stelzner DJ, Baisden RH, Goodman DC. The ventral lateral geniculate pars lateralis of the rat: synaptic organization and conditions for axonal sprouting. Cell Tissue Res 1976; 170: 435-454.

118. Stevenson JA. Growth of optic tract axons in nerve grafts in hamsters. Exp Neurol 1985; 87: 446-457.

119. Steward O, Cotman CW, Lynch GS. Growth of a new fiber projection in the brain of adult rats: reinnervation of the dentate gyrus by the contralateral entorhinal cortex following ipsilateral entorhinal lesions. Exp Brain Res 1974; 20: 45-66.

120. Sunderland S. Nerves and Nerve Injuries. Baltimore: Williams and Wilkins, 1968.

121. Sung $\mathrm{JH}$. Tangled mass of regenerated central nerve fibers (non myelinated central neuromas) in the central nervous system. J Neuropath Exp Neurol 1981; 40: 645-657.

122. Tabata T, Fukuda Y. Dendritic regrowth of retinal ganglion cells in adult rats. NeuroReport 1992; 3: 709712.

123. Thanos S, Mey J, Wild M. Treatment of the adult retina with microglia suppressing factors retards axotomy induced neuronal degeneration and enhances axonal regeneration in vivo and in vitro. $J$ Neurosci 1993; 13: 455-466.

124. Thanos S. Alterations in the morphology of ganglion cell dendrites in the adult rat retina after optic nerve transection and grafting of peripheral nerve segments. Cell Tissue Res 1988; 254: 599-609.

125. Tsukahara N. Synaptic plasticity in the mammalian central nervous system. Ann Rev Neurosci 1981; 4 : 351-379.

126. Vidal-Sanz M, Bray GM, Aguayo AJ. Regenerated synapses persist in the superior colliculus after the regrowth of retinal ganglion cell axons. J Neurocytol 1991; 20: 940-952.

127. Vidal-Sanz M, Bray GM, Villegas-Peréz MP, Thanos $\mathrm{S}$, Aguayo AJ. Axonal regeneration and synapse formation in the superior colliculus by retinal ganglion cells in the adult rat. J Neurosci 1987; 7: 2894-2909.

128. Vidal-Sanz M, Villegas-Peréz MP, Bray GM, Aguayo AJ. Persistent retrograde labeling of adult rat retinal ganglion cells with the carbocyanin dye diI. Exp Neurol 1988; 102: 92-101.

129. Villegas-Peréz MP, Vidal-Sanz M, Bray GM, Aguayo AJ. Influences of peripheral nerve grafts on the survival and regrowth of axotomized retinal ganglion cells in adult rats. J Neurosci 1988; 8: 265-280.

130. Villegas-Peréz MP, Vidal-Sanz M, Bray GM, Aguayo AJ. The distance of axotomy from the neuronal cell body influences the rate of retrograde degeneration but not long term survival of retinal ganglion cells. Soc Neurosci Abstr 1989; 15: 457.

131. Walker PD, McAllister JP. Minimal connectivity between neostriatal transplants and the host brain. Brain Res 1987; 425: 34-44.

132. Warkany J. Congenital Malformations. Chicago: Year Book Med Pub, 1971.

133. Watanabe $M$, Sawai $H$, and Fukuda $Y$. Axonal regeneration of retinal ganglion cells in the cat geniculocortical pathway. Brain Res 1991; 560: 330333.

134. Watanabe M, Sawai H, Fukuda Y. Number distribution and morphology of retinal ganglion cells with axons regenerated into peripheral nerve graft in adult. J Neurosci 1993; 13: 2105-2117.

135. Whalsten D. Heritable aspects of anomalous myelinated fibre tracts in the forebrain of the laboratory mouse. Brain Res 1974; 68: 1-18.

136. Xu ZC, Wilson CJ, Emson PC. Synaptic potentials evoked in spiny neurons in rat neostriatal grafts by cortical and thalamic stimulation. J Neurophysiol 1991; 65: 477-493.

137. Zhou FC, Buchwald N. Connectivities of the striatal grafts in adult rat brain: a rich afference and scant striatonigral efference. Brain Res 1989; 504: 15-30.

138. Zwimpfer TJ, Aguayo AJ, Bray GM. Synapse formation and preferential distribution in the granule cell layer by regenerating retinal ganglion cell axons guided to the cerebellum of adult hamsters. J Neurosci 1992; 12: 1144-1159. 

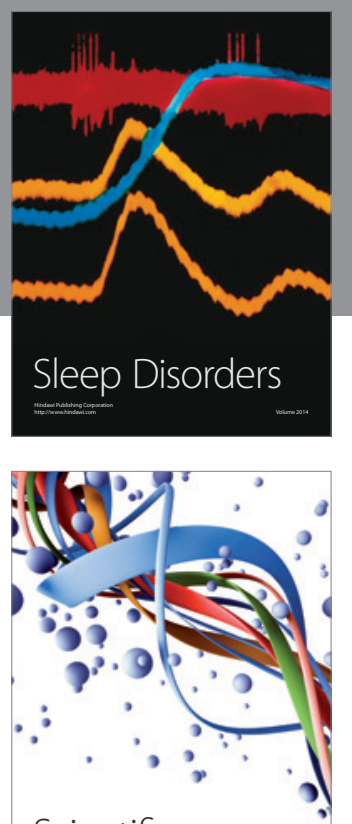

Scientifica
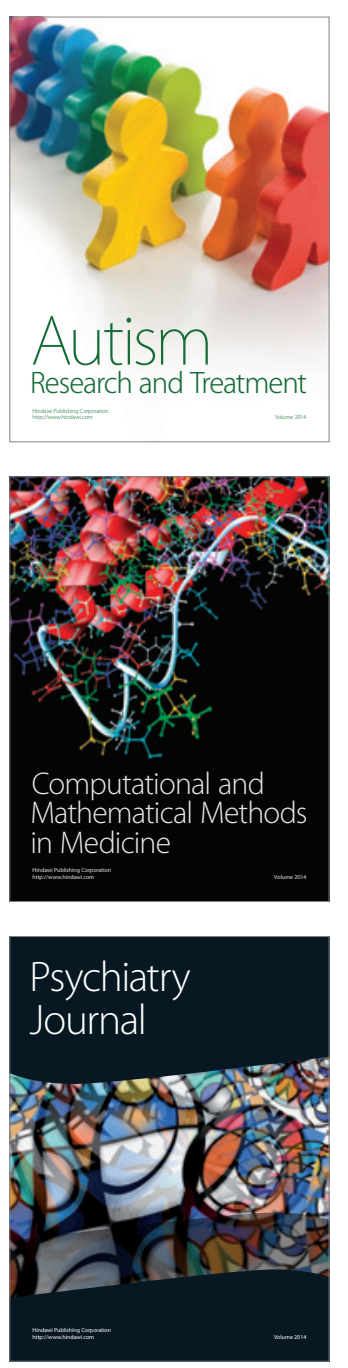
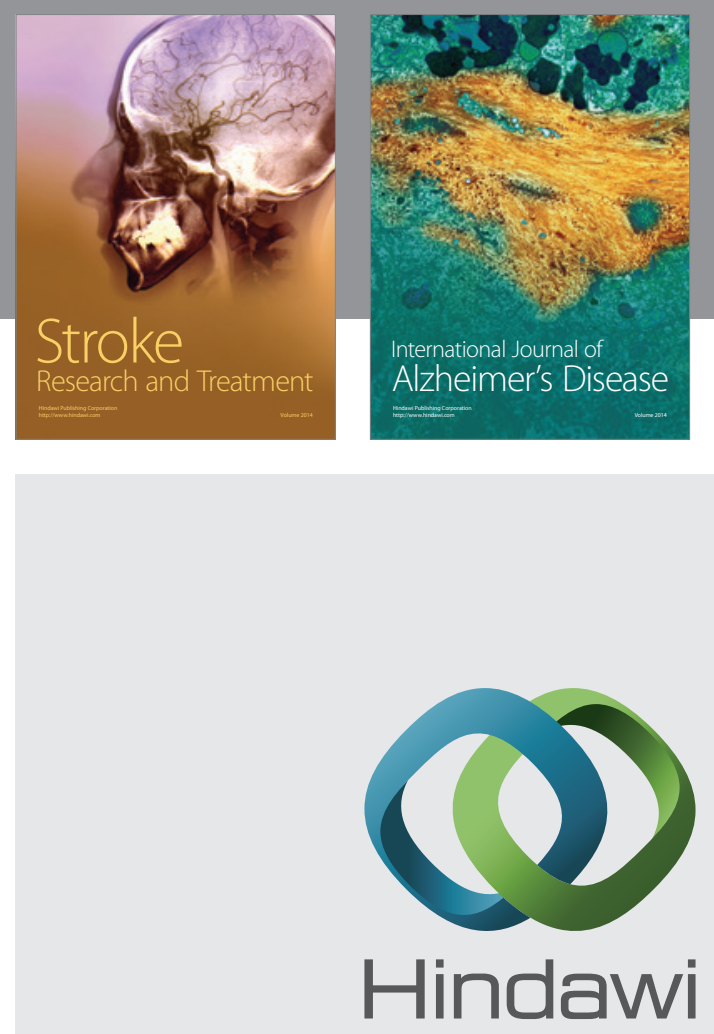

Submit your manuscripts at

http://www.hindawi.com
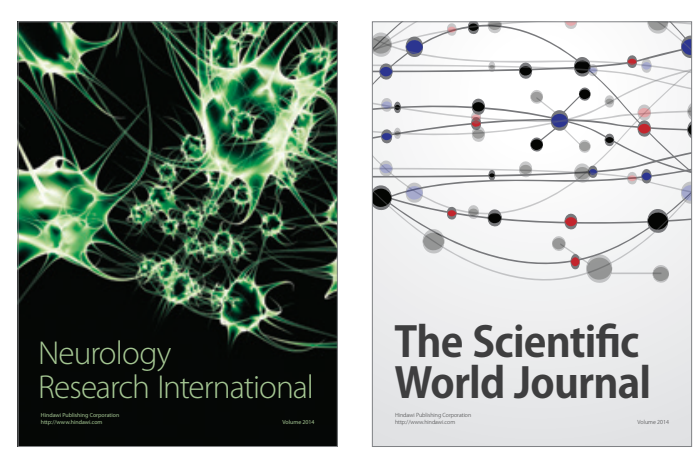

The Scientific World Journal

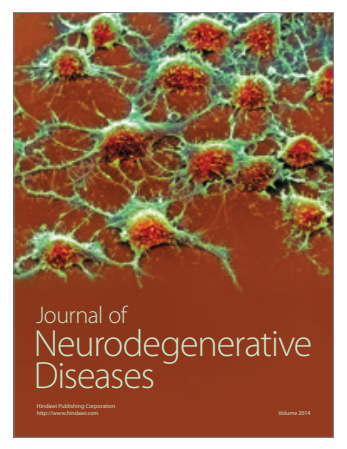

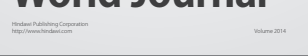

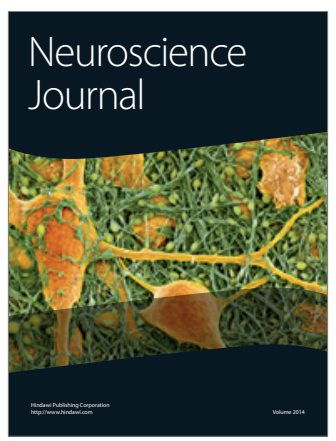

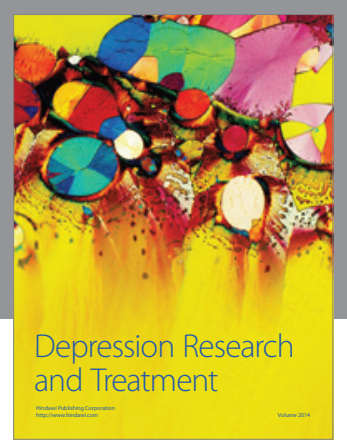
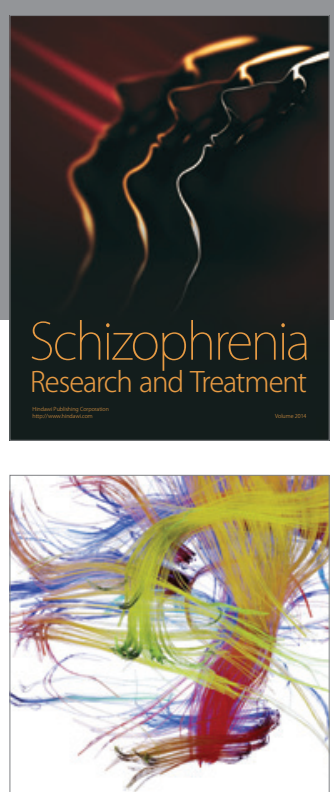

Brain Science

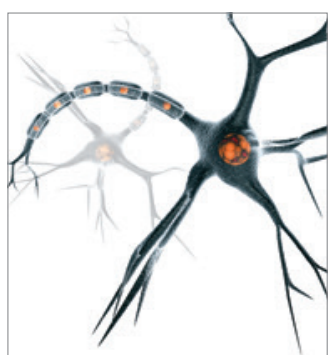

Neural Plasticity
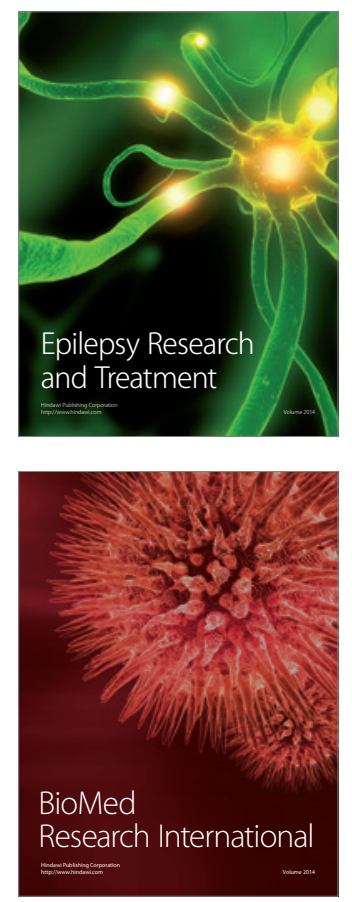

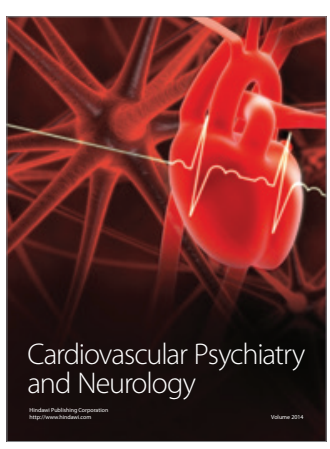

Parkinson's

Disease
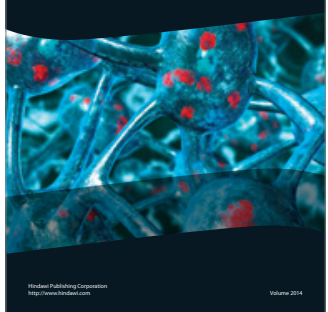